\title{
Use of Oxide Ligands in Designing Catalytic Active Sites
}

Edward L. Lee* and Israel E. Wachs

\section{1}

\section{Introduction}

Oxides of the group 5-7 metals ( $\mathrm{V}, \mathrm{Nb}, \mathrm{Ta}, \mathrm{Cr}, \mathrm{Mo}, \mathrm{W}$, and Re) supported on a high surface area oxide material $\left(\mathrm{SiO}_{2}, \mathrm{Al}_{2} \mathrm{O}_{3}, \mathrm{TiO}_{2}, \mathrm{ZrO}_{2}\right.$, etc.) are recognized as industrially important catalysts for numerous chemical reactions [1-11]. For example, these catalysts are utilized for $o$-xylene oxidation to phthalic anhydride $[12,13]$, methane/methanol oxidation to formaldehyde [14], and selective catalytic reduction (SCR) of NO with ammonia to $\mathrm{N}_{2}$ over supported vanadia catalysts [15-19]; SCR of NO with ammonia and selective oxidation of methane over supported molybdena catalysts [20-22]; olefin metathesis and hydrocarbon isomerization reactions over tungsta catalysts; and metathesis of olefins and alkanes over supported rhenia catalysts [23-25]. These supported metal oxide catalysts consist of highly dispersed surface metal oxide species - the catalytic active sites - anchored to the underlying oxide support. Over the decades, there have been many successful methods of controlling and anchoring the molecularly dispersed metal oxide phase by chemical vapor deposition (CVD) [26-28], incipient wetness impregnation [29-34], and precipitation [35-37]. The surface coverage of the metal oxide overlayer can vary from below to above monolayer coverage or the maximum dispersion limit, that is, maximum metal oxide dispersion before formation of crystalline metal oxide nanoparticles (NPs). Below monolayer surface coverage, only surface isolated (or monomeric) and surface polymeric metal oxide species are present on the support. At low surface coverage, only isolated surface metal oxide species are generally present [38]. Above monolayer coverage or maximum dispersion limit, crystalline metal oxide NPs are also present and reside on top of the molecularly dispersed surface metal oxide monolayer. Therefore, monolayer coverage or maximum dispersion limit is a critical parameter that allows distinguishing between two-dimensional molecularly dispersed surface metal oxide species and the three-dimensional NPs

\footnotetext{
*Present Work Address: The Dow Chemical Company Core Research and Development 1776 Building, Midland, MI 48674, USA
} 
present in supported metal oxide materials. For the purposes of simplifying and focusing the discussion, only $\mathrm{SiO}_{2}$-supported metal oxide catalysts at submonolayer coverages will be discussed in this chapter since the catalysis literature has demonstrated that only isolated surface metal oxide species are present at low coverage for supported $\mathrm{MO}_{x} / \mathrm{SiO}_{2}$ catalysts [14, 38-56].

The surface metal oxide species of supported metal oxide catalysts control the overall catalytic performance such as activity and selectivity. Thus, understanding the interactions of the surface metal oxide catalytic active sites with their environment (e.g., the underlying oxide support material and reactive environments) provides the ability to control and design these catalytic active sites. By spreading the catalytic active oxide layer over the underlying oxide support layers, the interfacial interaction of these "monolayer" catalysts results in different structures and catalytic properties than their bulk metal oxide counterparts [57, 58]. Therefore, recent studies have focused on characterizing the bridging $\mathrm{M}-\mathrm{O}-$ support bond for the design and control of the catalytic performance. The focus of this chapter will be to systematically surface modify the $\mathrm{SiO}_{2}$ support with surface $\mathrm{AlO}_{x}, \mathrm{TiO}_{x}$, and $\mathrm{ZrO}_{x}$ species (the oxide ligands). The group 5-7 transition metal oxides $\left(\mathrm{V}_{2} \mathrm{O}_{5}, \mathrm{MoO}_{3}\right.$, and $\left.\mathrm{Re}_{2} \mathrm{O}_{7}\right)$ will then be anchored onto the surface-modified $\mathrm{SiO}_{2}$ support by means of incipient wetness impregnation of soluble precursors and calcination. The $\mathrm{V}_{2} \mathrm{O}_{5}, \mathrm{MoO}_{3}$, and $\mathrm{Re}_{2} \mathrm{O}_{7}$ catalytic active sites were chosen because of their dominant redox characteristics that will allow comparison of their reactivity properties. These "multilayered" supported $\mathrm{M}_{1} \mathrm{O}_{x} / \mathrm{M}_{2} \mathrm{O}_{x} / \mathrm{SiO}_{2}$ catalysts will then be characterized and examined for their surface chemistry against the model supported $\mathrm{MO}_{x} / \mathrm{SiO}_{2}$ systems to understand the influence of the oxide ligands on the molecular/electronic structures and catalytic performance of the surface metal oxide species.

In keeping with the theme of the book for new approaches to synthesis and characterization of heterogeneous catalysts, this chapter will focus on the oxide ligand of the "multilayered" supported $\mathrm{M}_{1} \mathrm{O}_{x} / \mathrm{M}_{2} \mathrm{O}_{x} / \mathrm{SiO}_{2}$ catalysts by characterizing the surface $\mathrm{M}_{1} \mathrm{O}_{x}$ molecular and electronic structures and investigating the catalytic reactivity for oxidative dehydrogenation of methanol to formaldehyde. The molecular and electronic structures of the supported $\mathrm{M}_{1} \mathrm{O}_{x} / \mathrm{M}_{2} \mathrm{O}_{x} / \mathrm{SiO}_{2}$ catalysts will be determined with in situ Raman and UV-Vis diffuse reflectance spectroscopy (DRS) spectroscopy, respectively, under various environments (e.g., dehydrated, oxidative, reductive, and isotopic exchange) to investigate the fundamental interactions between the surface metal oxide overlayer $\left(\mathrm{M}_{1} \mathrm{O}_{x}\right)$ and the surface oxide modifiers $\left(\mathrm{M}_{2} \mathrm{O}_{x}\right)$ on the silica support. Time-resolved Raman spectra for reductive and isotopic oxygen exchange studies will provide additional insights into the dynamic nature of these catalytic active sites. The catalytic surface reactivity will be chemically probed via $\mathrm{CH}_{3} \mathrm{OH}$ temperature-programmed surface reaction $\left(\mathrm{CH}_{3} \mathrm{OH}-\mathrm{TPSR}\right)$ spectroscopy that will provide the surface kinetics and nature of the catalytic active sites (redox, acidic, or basic). Theoretical modeling results via computational density functional theory (DFT) from the literature will be referenced where appropriate. This systematic approach to supported metal oxide catalysts will assist in the establishment of molecular structure-reactivity relationship for designing and controlling surface metal oxide catalytic active sites. 
1.3 Characterization of $\mathrm{AlO}_{x}, \mathrm{TiO}_{x}$, and $\mathrm{ZrO}_{x}$ Surface-Modified $\left.\mathrm{SiO}_{2}\right|^{3}$

\section{2}

\section{Molecular Structural Determination of Supported Metal Oxide Catalysts with In Situ Raman Spectroscopy}

Raman spectroscopic studies in the late 1970s first reported the detection of surface metal oxide species for supported $\mathrm{MoO}_{3}$ [59-61], $\mathrm{WO}_{3}$ [62], $\mathrm{V}_{2} \mathrm{O}_{5}$ [63, 64], and $\mathrm{Re}_{2} \mathrm{O}_{7}$ [65] catalysts. These studies were followed by in situ Raman measurements in the early $1980 \mathrm{~s}$, where the gas phase environment and temperature of the catalyst could be controlled [66-70]. Detection of the reversible surface structures when exposed to hydrated and dehydrated conditions was demonstrated during this period [66]. These earlier experimental breakthroughs and with further advances in Raman technology allowed for the characterization of the surface structures of mixed metal oxide catalysts [58]. New approaches for in situ Raman spectroscopic measurements of catalytic surfaces are now undertaken via measurements under reductive, isotopic $\mathrm{D}_{2} \mathrm{O}-\mathrm{H}_{2} \mathrm{O}$ and ${ }^{16} \mathrm{O}-{ }^{18} \mathrm{O}$ exchange environments coupled with time-resolved spectroscopy. These approaches provide new fundamental insights that enable the molecular structural determination of the catalytic active surface metal oxide sites present in supported metal oxide catalysts.

It is important to recall that isotopic ${ }^{16} \mathrm{O}-{ }^{18} \mathrm{O}$ exchange results in band splitting. Based on vibrational theory, monoxo species are expected to exhibit two Raman vibrations $\left(\mathrm{M}={ }^{16} \mathrm{O}\right.$ and $\left.\mathrm{M}={ }^{18} \mathrm{O}\right)$; dioxo species are projected to give rise to three Raman vibrations $\left({ }^{16} \mathrm{O}=\mathrm{M}={ }^{16} \mathrm{O},{ }^{18} \mathrm{O}=\mathrm{M}={ }^{16} \mathrm{O}\right.$, and $\left.{ }^{18} \mathrm{O}=\mathrm{M}={ }^{18} \mathrm{O}\right)$; and trioxo species are expected to exhibit four Raman vibrations $\left(\mathrm{M}\left(={ }^{16} \mathrm{O}\right)_{3},{ }^{18} \mathrm{O}=\mathrm{M}\left(={ }^{16} \mathrm{O}\right)_{2}\right.$, $\left({ }^{18} \mathrm{O}=\right)_{2} \mathrm{M}={ }^{16} \mathrm{O}$, and $\left.\mathrm{M}\left(={ }^{18} \mathrm{O}\right)_{3}\right)[71-75]$. The position of the vibrational shifts can be estimated using a simple $\mathrm{M}-\mathrm{O}$ diatomic oscillator model for the isotopic ratio:

$$
\left[\frac{v_{\mathrm{O}-\mathrm{M}}^{16}}{v_{\mathrm{O}-\mathrm{M}}^{18}}\right]=\frac{\frac{1}{2 \pi c} \sqrt{\left(k\left(\frac{1}{m_{\mathrm{M}}}+\frac{1}{m_{16}}\right)\right)}}{\frac{1}{2 \pi c} \sqrt{\left(k\left(\frac{1}{m_{\mathrm{M}}}+\frac{1}{m_{18}}\right)\right)}}=\frac{\sqrt{\left(\frac{1}{m_{\mathrm{M}}}+\frac{1}{m_{16}}\right)}}{\sqrt{\left(\frac{1}{m_{\mathrm{M}}}+\frac{1}{m_{18}}\right)}}
$$

where $v$ is the frequency of the $\mathrm{M}-\mathrm{O}$ bond $\left(\mathrm{cm}^{-1}\right), k$ is the force constant, and $m$ is the mass of the transition metal ion or oxygen [71, 73].

\section{3}

\section{Characterization of $\mathrm{AlO}_{x}, \mathrm{TiO}_{x}$, and $\mathrm{ZrO}_{x}$ Surface-Modified $\mathrm{SiO}_{2}$}

The surface of $\mathrm{SiO}_{2}$ was modified by the deposition on the surface of $\mathrm{M}_{2} \mathrm{O}_{x}\left(\mathrm{AlO}_{x}, \mathrm{TiO}_{x}\right.$, or $\mathrm{ZrO}_{x}$ ) species. For each supported $\mathrm{M}_{2} \mathrm{O}_{x} / \mathrm{SiO}_{2}$ system, the surface-modified $\mathrm{SiO}_{2}$ support consists of $5 \% \mathrm{M}_{2} \mathrm{O}_{x} / \mathrm{SiO}_{2}$, which is below the maximum dispersion limit for these oxides on $\mathrm{SiO}_{2}$. The in situ Raman spectra of the dehydrated supported $\mathrm{M}_{2} \mathrm{O}_{x} / \mathrm{SiO}_{2}$ samples are presented in Figure 1.1 (left) and do not exhibit any new significant spectral features as compared to the original $\mathrm{SiO}_{2}$ support, with the exception of $\mathrm{TiO}_{x} / \mathrm{SiO}_{2}$, which will be discussed below. The deposition of alumina, titania, and zirconia on the silica support causes a decrease in the intensity of the band 
$4 \mid 1$ Use of Oxide Ligands in Designing Catalytic Active Sites
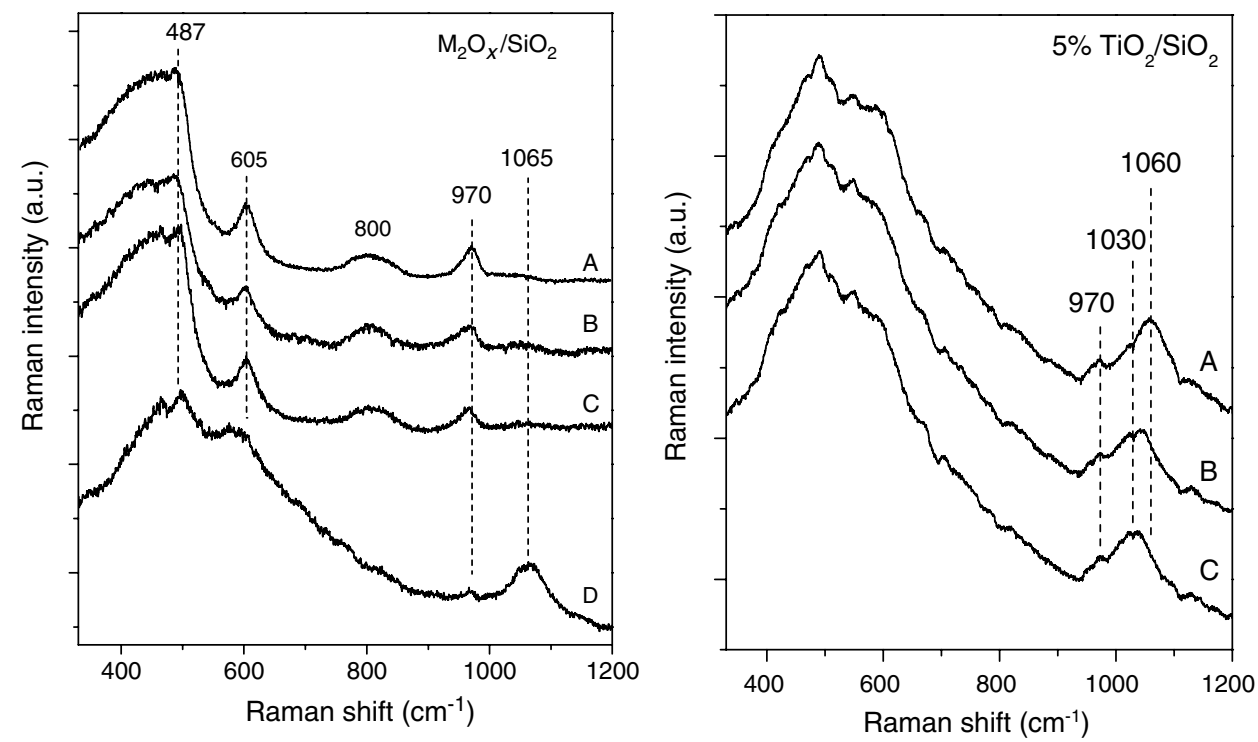

Figure 1.1 (Left) In situ Raman spectra of (A) pure and unmodified $\mathrm{SiO}_{2}$ and surface-modified $\mathrm{SiO}_{2}$ with (B) $5 \% \mathrm{ZrO}_{x},(\mathrm{C}) 5 \% \mathrm{AlO}_{x}$, and (D) $5 \% \mathrm{TiO}_{x}$ oxide ligands using $325 \mathrm{~nm}$ excitation energy at $500^{\circ} \mathrm{C}$. (Right) Time-resolved in situ Raman spectra of $5 \% \mathrm{TiO}_{x} / \mathrm{SiO}_{2}$ during $\mathrm{H}_{2}{ }^{18} \mathrm{O}$ exposure after (A) $0 \mathrm{~min}$, (B) $30 \mathrm{~min}$, and (C) $80 \mathrm{~min}$.

at $970 \mathrm{~cm}^{-1}$ of the $\mathrm{Si}-\mathrm{OH}$ vibration and indicates consumption of the $\mathrm{Si}-\mathrm{OH}$ surface hydroxyls. This decrease is further confirmed by in situ near-IR DRS at $7315 \mathrm{~cm}^{-1}(2 \mathrm{v})$. The surface modification of the $\mathrm{SiO}_{2}$ surface by the deposited oxides leads to direct interactions with the silica surface hydroxyl groups, resulting in the broadening of the $970 \mathrm{~cm}^{-1}$ band, and in the $\mathrm{ZrO}_{2} / \mathrm{SiO}_{2}$ spectrum, its shift toward lower wavenumbers $\left(\sim 940 \mathrm{~cm}^{-1}\right)$, which is suggestive of bridging $\mathrm{Zr}-\mathrm{O}-\mathrm{Silinkages}$. Therefore, the $\mathrm{AlO}_{x}$, $\mathrm{ZrO}_{x}$, and $\mathrm{TiO}_{x}$ surface modifiers anchor to the silica at the $\mathrm{Si}-\mathrm{OH}$ site to create a surface metal oxide layer with residual exposed $\mathrm{Si}-\mathrm{OH}$ species also present.

Additional Raman features are present, however, for the supported $\mathrm{TiO}_{x} / \mathrm{SiO}_{2}$ sample in Figure 1.1 (left). The transverse-optical (TO) mode of the silica network at $1065 \mathrm{~cm}^{-1}$, assigned to perturbed $\mathrm{Si}\left(-\mathrm{O}^{-}\right)_{2}$ and $\mathrm{Si}-\mathrm{O}^{-}$silica vibrations from the formation of $\mathrm{Ti}-\mathrm{O}-\mathrm{Si}$ bridging bond, appears to be resonance Raman enhanced with the $325 \mathrm{~nm}$ excitation, and the broad band at $550-600 \mathrm{~cm}^{-1}$ is suggestive of a small amount of polymeric $\mathrm{Ti}-\mathrm{O}-\mathrm{Ti}$ species. The supported $\mathrm{TiO}_{x} / \mathrm{SiO}_{2}$ sample was exposed to isotopic ${ }^{18} \mathrm{O}_{2}$ and monitored with time-resolved in situ Raman, see Figure 1.1 (right), to determine if the $\sim 1065 \mathrm{~cm}^{-1}$ band is related to the TO mode of the silica network or possibly the $\mathrm{Ti}=\mathrm{O}$ bond. The isotopic oxygen exchange resulted in the band shift from $\sim 1060$ to $\sim 1030 \mathrm{~cm}^{-1}$, which exactly corresponds to that of the TO vibration [76] since $\mathrm{Ti}={ }^{18} \mathrm{O}$ should shift to $1015 \mathrm{~cm}^{-1}$ for a simple $\mathrm{Ti}-\mathrm{O}$ diatomic oscillator (see Equation 1.1).

Extensive characterization experiments under dehydrated conditions have also been conducted by means of in situ IR, UV-Vis DRS, XPS, XANES, and ${ }^{27} \mathrm{Al}$ NMR, 
1.5 Molecular Structure of Dehydrated Supported $\mathrm{V}_{2} \mathrm{O}_{5} / \mathrm{SiO}_{2} \mid \mathbf{5}$

which provide additional molecular information about the supported $\mathrm{MO}_{x}$ phases on $\mathrm{SiO}_{2}$ [77-80]. The supported $5 \% \mathrm{TiO}_{2} / \mathrm{SiO}_{2}$ and $5 \% \mathrm{ZrO}_{2} / \mathrm{SiO}_{2}$ samples consist of $100 \%$ dispersed surface $\mathrm{TiO}_{x}$ and $\mathrm{ZrO}_{x}$ species on the $\mathrm{SiO}_{2}$ support. The surface $\mathrm{TiO}_{x}$ species are present as $\mathrm{TiO}_{4}$ and $\mathrm{TiO}_{5}$ coordinated species and the former dominates at the lower $\mathrm{TiO}_{x}$ content (such as $5 \% \mathrm{TiO}_{2} / \mathrm{SiO}_{2}$ ). The coordination environments of the dehydrated surface $\mathrm{ZrO}_{x}$ species have yet to be determined. The supported $5 \% \mathrm{Al}_{2} \mathrm{O}_{3} /$ $\mathrm{SiO}_{2}$ sample primarily contains surface $\mathrm{AlO}_{4}$ coordination with a minor amount of surface $\mathrm{AlO}_{5}$ species [77]. In summary, supported $5 \% \mathrm{TiO}_{2} / \mathrm{SiO}_{2}$ sample consists of $(\mathrm{OH})-\mathrm{Ti}-(\mathrm{O}-\mathrm{Si})_{3}$, and the $5 \% \mathrm{Al}_{2} \mathrm{O}_{3} / \mathrm{SiO}_{2}$ consists of $\left(\mathrm{O}^{-}\right)-\mathrm{Al}-(\mathrm{O}-\mathrm{Si})_{3}$ where the extra proton (Bronsted acid site) is on the bridging oxygen in the $\mathrm{Al}-\mathrm{O}-\mathrm{Si}$ bond.

\section{4}

\section{Anchoring Site of Surface $\mathrm{M}_{1} \mathrm{O}_{x}$ Species on Supported $\mathrm{M}_{2} \mathrm{O}_{x} / \mathrm{SiO}_{2}$}

The supported $\mathrm{M}_{1} \mathrm{O}_{x}$ phases areall found to be presentas two-dimensional surface metal oxide species on the $\mathrm{M}_{2} \mathrm{O}_{x} / \mathrm{SiO}_{2}$ supports, as will be shown below with Raman spectroscopy. The anchoring site of the surface $\mathrm{M}_{1} \mathrm{O}_{x}$ species takes place on exposed surface $-\mathrm{OH}$ sites and is related to the acidic/basic nature of the surface $-\mathrm{OH}$ groups. It is well established that anchoring of acidic surface $\mathrm{M}_{1} \mathrm{O}_{x}$ initially occurs at the most basic surface -OH groups, followed by the neutral surface -OH groups, and finally, the most acidic surface $-\mathrm{OH}$ groups [81]. The acidity of the surface $-\mathrm{OH}$ groups is related to the electronegativity of the oxide support cation and increases with the support cation electronegativity $(\mathrm{Zr} \sim \mathrm{Ti}<\mathrm{Al}<\mathrm{Si})$ [82]. Consequently, the acidic surface $\mathrm{M}_{1} \mathrm{O}_{x}$ species preferentially anchor to the more basic surface $\mathrm{Zr}-\mathrm{OH}, \mathrm{Ti}-\mathrm{OH}$, and $\mathrm{Al}-\mathrm{OH}$ sites over the more acidic surface $\mathrm{Si}-\mathrm{OH}$ sites. This preferential anchoring is best demonstrated by the Raman spectra of the supported $\mathrm{WO}_{x} / \mathrm{SiO}_{2}$ and $\mathrm{WO}_{x} / \mathrm{AlO}_{x} / \mathrm{SiO}_{2}$ catalytic systems, as shown in Figure 1.2. The supported $\mathrm{WO}_{3} / \mathrm{SiO}_{2}$ gives rise to a dominant Raman band at $982 \mathrm{~cm}^{-1}\left(\right.$ dioxo $\left.v_{\mathrm{s}}\left(\mathrm{W}(=\mathrm{O})_{2}\right)\right)$ and a minor Raman band at $1014 \mathrm{~cm}^{-1}$ $\left(\right.$ monoxo $\left._{\mathrm{s}}(\mathrm{W}=\mathrm{O})\right)$ that transform to monoxo $v_{\mathrm{s}}(\mathrm{W}=\mathrm{O})$ species with a Raman band at $1020 \mathrm{~cm}^{-1}$ for the supported $\mathrm{WO}_{3} / \mathrm{Al}_{2} \mathrm{O}_{3} / \mathrm{SiO}_{2}$ catalyst system. Furthermore, the monoxo $v_{\mathrm{s}}(\mathrm{W}=\mathrm{O})$ Raman band position at $1020 \mathrm{~cm}^{-1}$ matches that for monoxo $v_{\mathrm{s}}(\mathrm{W}=\mathrm{O})$ species present in the supported $\mathrm{WO}_{3} / \mathrm{Al}_{2} \mathrm{O}_{3}$ catalysts [83]. These Raman spectral changes clearly reflect the preferential anchoring of the surface $\mathrm{WO}_{x}$ species at the surface $\mathrm{AlO}_{x}$ sites over exposed $\mathrm{SiO}_{2}$ sites on the surface-modified $\mathrm{SiO}_{2}$ support. The preferential anchoring of the surface $\mathrm{M}_{1} \mathrm{O}_{x}$ species at the surface $\mathrm{M}_{2} \mathrm{O}_{x}$ species over the exposed $\mathrm{SiO}_{2}$ support sites is a general phenomenon for anchoring of group 5-7 transition metal oxides on the surface-modified $\mathrm{SiO}_{2}$ support.

\section{5}

\section{Molecular Structure of Dehydrated Supported $\mathrm{V}_{2} \mathrm{O}_{5} / \mathrm{SiO}_{2}$ and $\mathrm{V}_{2} \mathrm{O}_{5} / \mathrm{M}_{2} \mathrm{O}_{x} / \mathrm{SiO}_{2}$ Catalyst Systems}

The surface vanadium oxide species in the dehydrated $\mathrm{V}_{2} \mathrm{O}_{5} / \mathrm{SiO}_{2}$ catalyst exhibit a sharp and intense Raman vibration at $1038 \mathrm{~cm}^{-1}$, as shown in Figure 1.3 (left), curve 


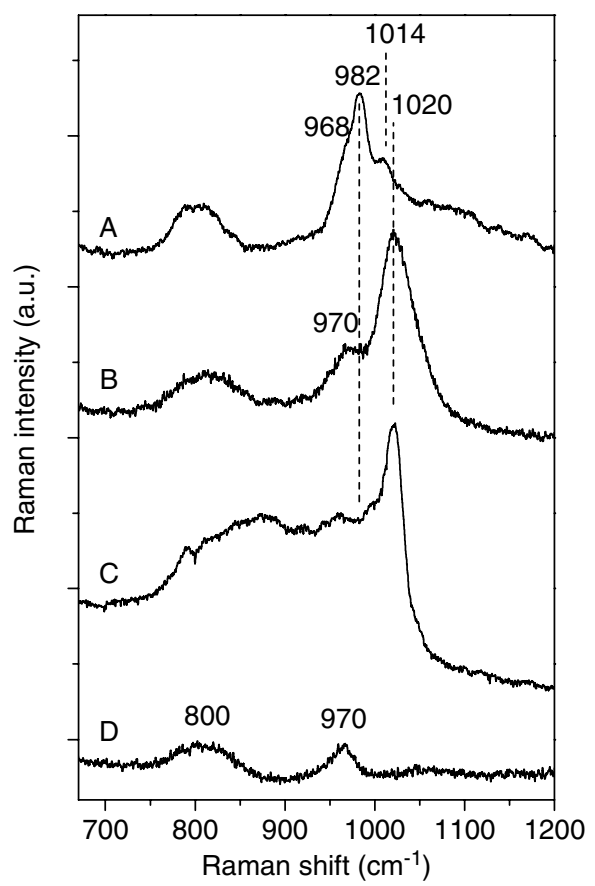

Figure 1.2 In situ Raman spectra under oxidizing conditions using $532 \mathrm{~nm}$ excitation energy of (A) $6 \% \mathrm{WO}_{3} / \mathrm{SiO}_{2}$, (B) $3 \% \mathrm{WO}_{3} / 5 \%$ $\mathrm{Al}_{2} \mathrm{O}_{3} / \mathrm{SiO}_{2}$, (C) $20 \% \mathrm{WO}_{3} / \mathrm{Al}_{2} \mathrm{O}_{3}$, and (D) pure $\mathrm{SiO}_{2}$ for reference.

labeled $\mathrm{A}$, and has been assigned to the terminal $v_{\mathrm{S}}(\mathrm{V}=\mathrm{O})$ stretch of isolated surface $\mathrm{VO}_{4}$ species [39-45]. This Raman band position is also independent of exposure to $\mathrm{D}_{2} \mathrm{O}$ at elevated temperatures indicating that there are no $\mathrm{V}-\mathrm{OH}$ functionalities (not shown for brevity). The position of the terminal $\mathrm{V}=\mathrm{O}$ vibration at $1038 \mathrm{~cm}^{-1}$ is consistent with the monoxo $\mathrm{V}=\mathrm{O}$ structure present in $\mathrm{H}_{3} \mathrm{SiMo}_{11} \mathrm{VO}_{40}$ Keggin structure $\left(1034 \mathrm{~cm}^{-1}\right)$ and $\left(\mathrm{Ph}_{3} \mathrm{SiO}\right)_{3} \mathrm{~V}=\mathrm{O}\left(1022 \mathrm{~cm}^{-1}\right)$, as well as with DFT calculations (1038-1047 $\mathrm{cm}^{-1}$ ) for the simple gas phase monomer structure, $\mathrm{O}=\mathrm{V}\left(\mathrm{OCH}_{3}\right)_{3}$ and monomeric polyhedral oligomeric silsesquioxanes [84-86]. Furthermore, dioxo $\mathrm{O}=\mathrm{V}=\mathrm{O}$ structures vibrate at a wavenumber $\sim 970\left(v_{\mathrm{s}}\right) / 960\left(v_{\mathrm{as}}\right) \mathrm{cm}^{-1}$ [73]. The terminal $v_{\mathrm{s}}(\mathrm{V}=\mathrm{O})$ vibration is accompanied by weaker bands at 340 and $905 \mathrm{~cm}^{-1}$, assigned to the bending $(\delta) \mathrm{V}-\mathrm{O}$ and stretching $\mathrm{V}-\mathrm{O}-\mathrm{Si}$ modes, respectively. The weak shoulder band at $1070 \mathrm{~cm}^{-1}$ is characteristic of the silica network TO mode and has been assigned to perturbed $\mathrm{Si}\left(-\mathrm{O}^{-}\right)_{2}$ and $\mathrm{Si}-\mathrm{O}^{-}$silica vibrations that are also indicative of the formation of bridging $\mathrm{V}-\mathrm{O}-\mathrm{Si}$ bonds [40]. The partial reduction of the 1038,905 , and $340 \mathrm{~cm}^{-1}$ Raman bands at $600^{\circ} \mathrm{C}$ under the reducing $\mathrm{H}_{2}$ environment, shown in curve $\mathrm{B}$ of Figure 1.3 (left), confirms the assigned $\mathrm{V}=\mathrm{O}$, $\mathrm{V}-\mathrm{O}-\mathrm{Si}$ and bending $\mathrm{V}-\mathrm{O}$ vibrations to surface $\mathrm{V}-\mathrm{O}$ vibrations [43]. Comparison of the Raman spectra for the reduced supported $\mathrm{V}_{2} \mathrm{O}_{5} / \mathrm{SiO}_{2}$ catalyst sample with that of the $\mathrm{SiO}_{2}$ support (see curve $\mathrm{C}$ of Figure 1.3 (left)) reveals the decrease of the silica 970 and $605 \mathrm{~cm}^{-1}$ bands relative to the silica $800 \mathrm{~cm}^{-1}$ band upon deposition of 
1.5 Molecular Structure of Dehydrated Supported $\mathrm{V}_{2} \mathrm{O}_{5} / \mathrm{SiO}_{2} \mid 7$
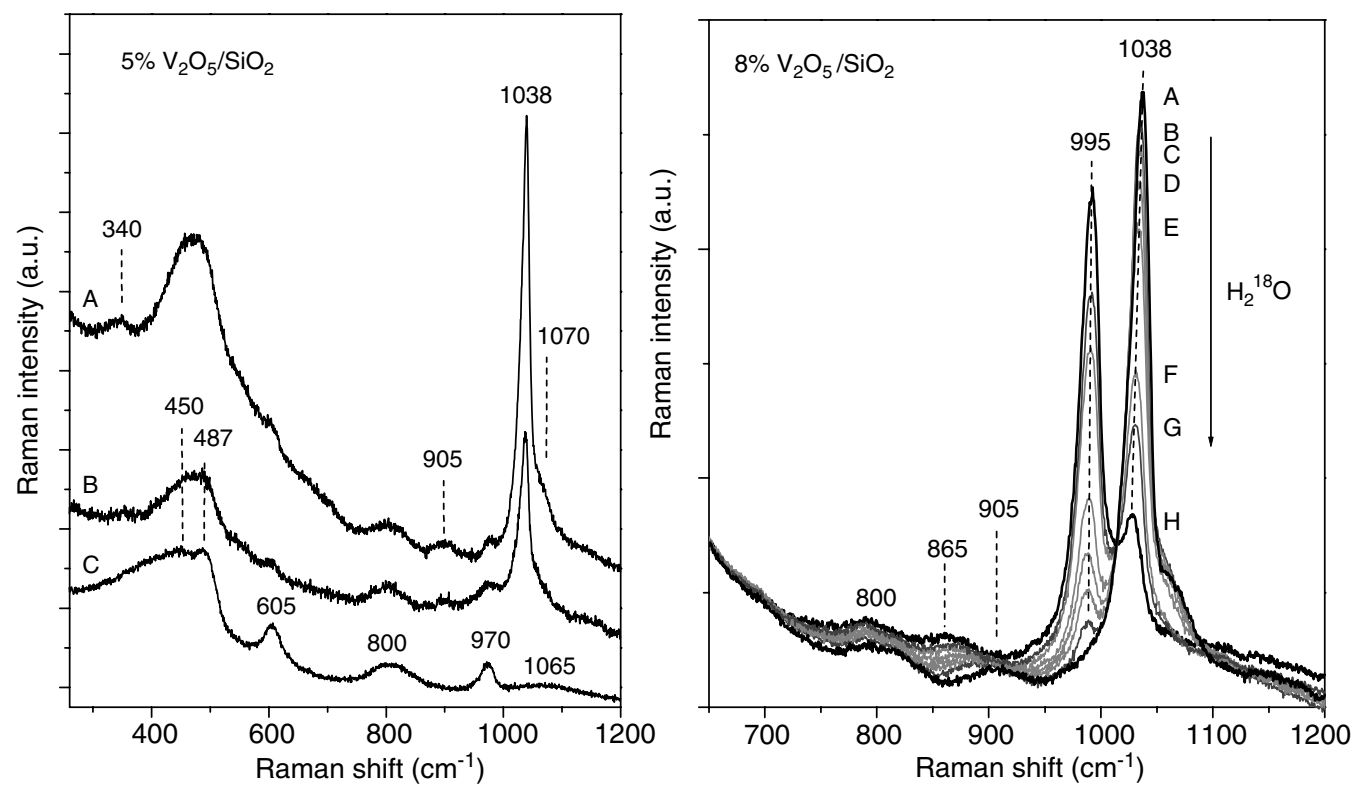

Figure 1.3 (Left) In situ Raman spectra of supported $5 \% \mathrm{~V}_{2} \mathrm{O}_{5} / \mathrm{SiO}_{2}$ using $532 \mathrm{~nm}$

Reproduced from Ref. [55]. (Right) Timeresolved in situ Raman spectra of supported $8 \%$ excitation energy under $(A)$ oxidizing conditions $\mathrm{V}_{2} \mathrm{O}_{5} / \mathrm{SiO}_{2}$ during $\mathrm{H}_{2}{ }^{18} \mathrm{O}$ exposure after $(\mathrm{A})$ at $450^{\circ} \mathrm{C}$ and (B) hydrogen reducing conditions $0 \mathrm{~min},(B) 10 \mathrm{~min}$, (C) $20 \mathrm{~min}$, (D) $30 \mathrm{~min},(\mathrm{E})$ $\left(5 \% \mathrm{H}_{2} / \mathrm{Ar}\right.$ at $\left.600^{\circ} \mathrm{C}\right)$. The dehydrated $\mathrm{SiO}_{2}$ support is shown for reference in (C). $40 \mathrm{~min},(\mathrm{~F}) 70 \mathrm{~min},(\mathrm{G}) 90 \mathrm{~min}$, and $(\mathrm{H}) 130 \mathrm{~min}$. Reproduced from Ref. [56].

surface vanadia species, indicating the preferential anchoring of the surface vanadia species at the isolated $\mathrm{SiO}_{2}$ support surface hydroxyls and the three-membered siloxane rings, respectively. Deuterated water experiments result in a shift of the $970 \mathrm{~cm}^{-1}$ band to $\sim 955 \mathrm{~cm}^{-1}$ due to the exchange of $\mathrm{Si}-(\mathrm{OH})$ to $\mathrm{Si}-(\mathrm{OD})$ as seen with the pure silica [55]. Additional insight is provided by time-resolved isotopic oxygen exchange of the dehydrated supported $\mathrm{V}_{2} \mathrm{O}_{5} / \mathrm{SiO}_{2}$ catalyst, shown in Figure 1.3 (right), and results in splitting of the surface $\mathrm{V}=\mathrm{O}$ band to 1038 and $995 \mathrm{~cm}^{-1}$ (assigned to $v_{\mathrm{s}}\left(\mathrm{V}={ }^{16} \mathrm{O}\right)$ and $\mathrm{v}_{\mathrm{s}}\left(\mathrm{V}={ }^{18} \mathrm{O}\right)$, respectively) and shifting of the $\mathrm{V}-\mathrm{O}-\mathrm{Si}$ vibration from 905 to $865 \mathrm{~cm}^{-1}[56,72]$. The time-resolved Raman spectra reveal that the two symmetric $\mathrm{V}=\mathrm{O}$ bands remain at the same wavenumber during the exchange process. The shift from 1038 to $995 \mathrm{~cm}^{-1}$ closely matches the theoretical $\mathrm{V}={ }^{18} \mathrm{O}$ vibration at $993 \mathrm{~cm}^{-1}$ of a simple diatomic oscillator model [56].

The Raman spectra of the dehydrated supported $\mathrm{V}_{2} \mathrm{O}_{5} / \mathrm{TiO}_{2} / \mathrm{SiO}_{2}, \mathrm{~V}_{2} \mathrm{O}_{5} / \mathrm{ZrO}_{2} /$ $\mathrm{SiO}_{2}$, and $\mathrm{V}_{2} \mathrm{O}_{5} / \mathrm{Al}_{2} \mathrm{O}_{3} / \mathrm{SiO}_{2}$ catalysts are presented in Figure 1.4 (left) and give rise to a single sharp band at $\sim 1035 \mathrm{~cm}^{-1}$ from the $v_{\mathrm{s}}(\mathrm{V}=\mathrm{O})$ stretching mode of the dehydrated surface $\mathrm{VO}_{x}$ species. The similarity of the terminal $v_{\mathrm{s}}(\mathrm{V}=\mathrm{O})$ vibrations for the supported $\mathrm{VO}_{x} / \mathrm{M}_{2} \mathrm{O}_{x} / \mathrm{SiO}_{2}$ catalysts to that of the model supported $\mathrm{VO}_{x} / \mathrm{SiO}_{2}$ catalyst indicates that all these catalysts contain the same monoxo $\mathrm{V}=\mathrm{O}$ species. The constancy of the $\mathrm{V}=\mathrm{O}$ vibration indicates that the surface structure stays monoxo even with the addition of the surface modifiers, as depicted in Figure 1.4 (right). 

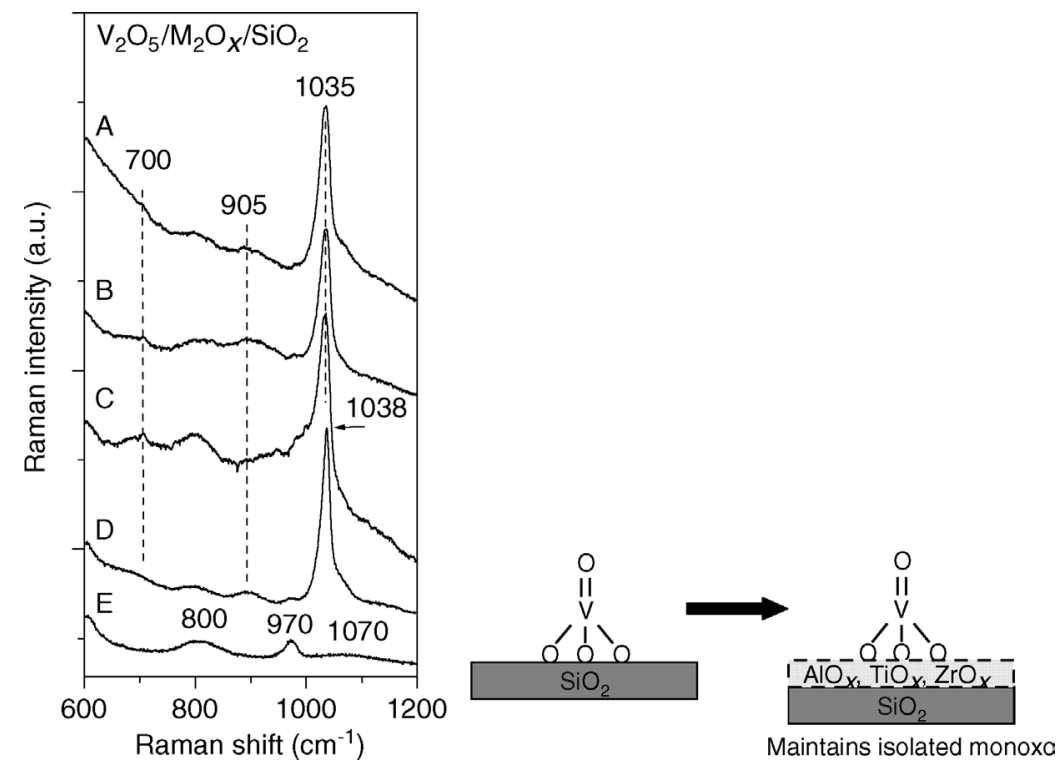

Figure 1.4 (Left) In situ Raman spectra $(532 \mathrm{~nm})$ of dehydrated supported (A) $5 \% \mathrm{~V}_{2} \mathrm{O}_{5} / \mathrm{TiO}_{x} / \mathrm{SiO}_{2}$, (B) $5 \% \mathrm{~V}_{2} \mathrm{O}_{5} / \mathrm{ZrO}_{x} / \mathrm{SiO}_{2}$, (C) $5 \% \mathrm{~V}_{2} \mathrm{O}_{5} / \mathrm{AlO}_{x} / \mathrm{SiO}_{2}$, and (D) $5 \% \mathrm{~V}_{2} \mathrm{O}_{5} / \mathrm{SiO}_{2}$ catalysts under oxidizing conditions at $600^{\circ} \mathrm{C}$. Pure dehydrated $\mathrm{SiO}_{2}$ spectrum (E) is provided for reference. Reproduced in part from refs. $[44,77,87-90]$. (Right) Schematic of dehydrated supported $\mathrm{VO}_{x}$ species on $\mathrm{SiO}_{2}$ and surface-modified silica.

Furthermore, there is no apparent ligand effect of the surface modifiers on the molecular structure of the surface $\mathrm{VO}_{x}$ species. A new weak Raman band at $\sim 700$ $\mathrm{cm}^{-1}$ is also present for the supported $\mathrm{VO}_{x} / \mathrm{M}_{2} \mathrm{O}_{x} / \mathrm{SiO}_{2}$ catalysts, which becomes more intense with increasing vanadia and additive concentrations and is tentatively assigned to the stretching mode of the corresponding $\mathrm{V}-\mathrm{O}-\mathrm{Al} / \mathrm{V}-\mathrm{O}-\mathrm{Zr} / \mathrm{V}-\mathrm{O}-\mathrm{Ti}$ bridging bonds.

\section{6}

\section{Molecular Structure of Dehydrated Supported $\mathrm{MoO}_{3} / \mathrm{SiO}_{2}$ and $\mathrm{MoO}_{3} / \mathrm{M}_{2} \mathrm{O}_{x} / \mathrm{SiO}_{2}$ Catalyst Systems}

The in situ Raman spectrum of dehydrated supported $\mathrm{MoO}_{3} / \mathrm{SiO}_{2}$ is presented in curve A of Figure 1.5 (left). The dehydrated surface molybdenum oxide species possess dioxo $(\mathrm{O}=)_{2} \mathrm{Mo}(-\mathrm{O}-\mathrm{Si})_{2}$ and monoxo $\mathrm{O}=\mathrm{Mo}(-\mathrm{O}-\mathrm{Si})_{4}$ structures that give rise to Raman bands for $v_{\mathrm{s}}\left(\mathrm{Mo}(=\mathrm{O})_{2}\right)$ at $\sim 976-988 \mathrm{~cm}^{-1}$ and $\mathrm{v}_{\mathrm{s}}(\mathrm{Mo}=\mathrm{O})$ at $1020 \mathrm{~cm}^{-1}$, respectively [91-97]. The corresponding dioxo $v_{\text {as }}\left(\mathrm{Mo}(=\mathrm{O})_{2}\right)$ stretch appears as a shoulder at $965-975 \mathrm{~cm}^{-1}$ and the weak vibration at $364 \mathrm{~cm}^{-1}$ is attributed to the bending $\delta(\mathrm{O}-\mathrm{Mo}-\mathrm{O})$ mode $[20,75,94-97]$. The surface $\mathrm{MoO}_{x}$ vibration at $1020 \mathrm{~cm}^{-1}$ is consistent with that of the monoxo $\mathrm{H}_{3} \mathrm{SiMo}_{12} \mathrm{O}_{40}$ Keggin structure $\left(1006 \mathrm{~cm}^{-1}\right)$ and DFT calculations predicting monoxo $(\mathrm{Si}-\mathrm{O}){ }_{4} \mathrm{Mo}=\mathrm{O}$ vibrations at $1014-1017 \mathrm{~cm}^{-1}$. 

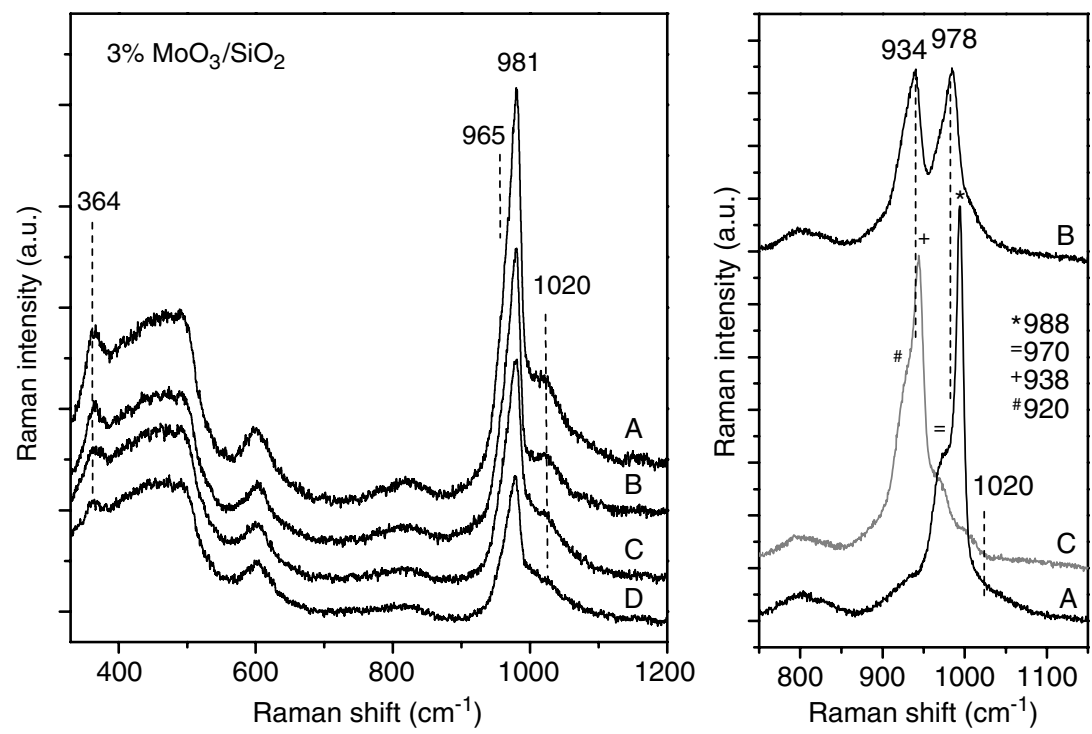

Figure 1.5 (Left) In situ Raman spectra $(325 \mathrm{~nm})$ of supported $3 \% \mathrm{MoO}_{3} / \mathrm{SiO}_{2}$ under $(\mathrm{A})$ oxidizing, dehydrated conditions at $500^{\circ} \mathrm{C}$, (B) reoxidation after $\mathrm{H}_{2}$ exposure, (C) $2 \% \mathrm{H}_{2} / \mathrm{He}$ exposure, and (D) $5 \% \mathrm{H}_{2} / \mathrm{He}$ exposure. Reproduced from Ref. [55]. (Right) Time-resolved in situ Raman spectra (325 nm) of supported $8 \% \mathrm{MoO}_{3} / \mathrm{SiO}_{2}$ during $\mathrm{H}_{2}{ }^{18} \mathrm{O}$ exposure after (A) $0 \mathrm{~min},(B) 13 \mathrm{~min}$, and (C) $100 \mathrm{~min}$.

Consequently, the surface molybdena vibrations present for the dehydrated supported $\mathrm{MoO}_{3} / \mathrm{SiO}_{2}$ catalyst samples at $976-988 \mathrm{~cm}^{-1}$ with the shoulder band at $965-975 \mathrm{~cm}^{-1}$ correspond to dioxo surface $\mathrm{O}=\mathrm{Mo}=\mathrm{O}$ species, consistent with DFT calculations predicting the dioxo $(\mathrm{Si}-\mathrm{O})_{2} \mathrm{Mo}(=\mathrm{O})_{2}$ vibration located at $995\left(\mathrm{v}_{\mathrm{s}}\right)$ and 977 $\left(v_{\mathrm{as}}\right)$, respectively. The expected weak bridging $\mathrm{Mo}-\mathrm{O}-\mathrm{Si}$ band is not readily observed in the $\sim 900-930 \mathrm{~cm}^{-1}$ region and may be overshadowed by the intense bands of the surface molybdena species. Upon exposure to reducing hydrogen environments, the surface $v_{\mathrm{s}}\left(\mathrm{Mo}(=\mathrm{O})_{2}\right)$ vibration present in the in situ Raman spectrum of curve $\mathrm{D}$ of Figure 1.5 (left) reduces its intensity to about a quarter of the fully oxidized intensity, which indicates partial reduction. Additionally, the decrease in intensity of the Raman bands at $364, \sim 965$, and $1020 \mathrm{~cm}^{-1}$ during the $\mathrm{H}_{2}$ reduction treatments confirms that these assignments are associated with $\mathrm{Mo}-\mathrm{O}$ vibrations. Oxidation of the partially reduced supported $\mathrm{MoO}_{3} / \mathrm{SiO}_{2}$ catalysts restores all the surface $\mathrm{MoO}_{x}$ vibrations as shown in curve B of Figure 1.5 (left).

The surface dioxo $v_{\mathrm{s}}$ and $v_{\mathrm{as}}\left(\mathrm{Mo}\left(={ }^{16} \mathrm{O}\right)_{2}\right)$ Raman bands at 988 and $970 \mathrm{~cm}^{-1}$ shift to 938 and $920 \mathrm{~cm}^{-1}$, respectively, after almost complete isotopic oxygen exchange of the corresponding $\mathrm{Mo}\left(={ }^{18} \mathrm{O}\right)_{2}$ species, and are presented in Figure 1.5 (right). The shift of approximately $-50 \mathrm{~cm}^{-1}$ is consistent with earlier IR literature observations, that the $990 \mathrm{~cm}^{-1}$ band shifts to $940 \mathrm{~cm}^{-1}$ during isotopic exchange from $\mathrm{Mo}^{16} \mathrm{O}$ to Mo ${ }^{18} \mathrm{O}$ species [97] and that the $970 \mathrm{~cm}^{-1}$ band shifts to $935 \mathrm{~cm}^{-1}$ for the $\mathrm{Mo}={ }^{16} \mathrm{O}$ to $\mathrm{Mo}={ }^{18} \mathrm{O}$ species [98], and with Raman spectra studies that the $988 \mathrm{~cm}^{-1}$ band shifts to $938 \mathrm{~cm}^{-1}$ [99]. The Raman band of the surface monoxo $\mathrm{v}_{\mathrm{s}}\left(\mathrm{Mo}={ }^{16} \mathrm{O}\right)$ species at 
$1020 \mathrm{~cm}^{-1}$ is not readily observed in Figure 1.5 (right) because of resonance enhancement of the vibrations of the surface dioxo species and the presence of a greater concentration of surface dioxo species at higher $\mathrm{MoO}_{x}$ loading (8 wt.\%). Consequently, only the isotopic shift of for surface dioxo species will be discussed. At intermediate extent of isotopic oxygen exchange, the band splitting occurs at $978 \mathrm{~cm}^{-1}$ of the $v_{\mathrm{s}}\left(\mathrm{Mo}\left(={ }^{16} \mathrm{O}\right)_{2}\right)$ vibration and at $934 \mathrm{~cm}^{-1}$ of the $v_{\mathrm{s}}\left(\mathrm{Mo}\left(={ }^{18} \mathrm{O}\right)_{2}\right)$ species. Note that the $v_{\mathrm{s}}\left(\mathrm{Mo}(=\mathrm{O})_{2}\right)$ vibration shifts from $988 \mathrm{~cm}^{-1}$, when the surface $\mathrm{MoO}_{4}$ contains $\sim 100 \%{ }^{16} \mathrm{O}$, to $978 \mathrm{~cm}^{-1}$, when the surface $\mathrm{MoO}_{4}$ is composed of a mixture of ${ }^{16} \mathrm{O}$ and ${ }^{18} \mathrm{O}$. No shift of any surface species (Raman bands at $\sim 965$, 976-991, and $1020 \mathrm{~cm}^{-1}$ ) is observed during $\mathrm{H}_{2} \mathrm{O}-\mathrm{D}_{2} \mathrm{O}$ exchange or during injection of pure $\mathrm{H}_{2} \mathrm{O}$, which is consistent with the absence of an $\mathrm{Mo}-\mathrm{OH}$ functionality. Therefore, shifting of the Raman bands is indicative of intermediate ${ }^{16} \mathrm{O}=\mathrm{Mo}={ }^{18} \mathrm{O}$ species, as suggested by DFT calculations. The DFT calculations predict that the $\mathrm{Mo}=\mathrm{O}$ component shows a shift of not more than $5-7 \mathrm{~cm}^{-1}\left(995\right.$ to $\sim 988 \mathrm{~cm}^{-1}$ ) from $v_{\mathrm{s}}\left(\mathrm{Mo}\left(={ }^{16} \mathrm{O}\right)_{2}\right)$ to $v_{\mathrm{s}}\left({ }^{16} \mathrm{O}=\mathrm{Mo}={ }^{18} \mathrm{O}\right)$ and one that is larger, $\sim 32 \mathrm{~cm}^{-1}$ ( $\sim 988$ to $\left.\sim 956 \mathrm{~cm}^{-1}\right)$, from $v_{\mathrm{s}}\left({ }^{16} \mathrm{O}=\mathrm{Mo}={ }^{18} \mathrm{O}\right)$ to $v_{\mathrm{s}}\left(\mathrm{Mo}\left(={ }^{18} \mathrm{O}\right)_{2}\right)$. Experimentally, the $\mathrm{Mo}=\mathrm{O}$ component shows an initial shift of $5-10 \mathrm{~cm}^{-1}\left(981-988\right.$ to $\left.976-978 \mathrm{~cm}^{-1}\right)$ followed by a larger one, of almost $-40 \mathrm{~cm}^{-1}$, to $\sim 933-938 \mathrm{~cm}^{-1}$, which represents the shift from $v_{\mathrm{s}}\left(\mathrm{Mo}\left(={ }^{16} \mathrm{O}\right)_{2}\right)$ to $\mathrm{v}_{\mathrm{s}}\left({ }^{16} \mathrm{O}=\mathrm{Mo}={ }^{18} \mathrm{O}\right)$ to $\mathrm{v}_{\mathrm{s}}\left(\mathrm{Mo}\left(={ }^{18} \mathrm{O}\right)_{2}\right)$. The $v_{\mathrm{as}}\left(\mathrm{Mo}\left(={ }^{16} \mathrm{O}\right)_{2}\right)$ shoulder vibration at $970 \mathrm{~cm}^{-1}$ that shifts $40-50 \mathrm{~cm}^{-1}$ to lower wavenumbers also closely follows the DFT calculations, where it is predict that the shift of $v_{\mathrm{as}}$ (Mo $\left.\left(={ }^{16} \mathrm{O}\right)_{2}\right)$ to $\mathrm{v}_{\text {as }}\left(\mathrm{Mo}\left(={ }^{18} \mathrm{O}\right)_{2}\right)$ is $-43 \mathrm{~cm}^{-1}\left(977\right.$ to $\left.\sim 934 \mathrm{~cm}^{-1}\right)$ after complete exchange. The shoulder at $\sim 920 \mathrm{~cm}^{-1}$ is also consistent with $v_{\text {as }}\left(\mathrm{Mo}\left(={ }^{18} \mathrm{O}\right)_{2}\right)$ and not the $\mathrm{Si}-{ }^{18} \mathrm{OH}$ vibration, which appears at $950 \mathrm{~cm}^{-1}$ (not shown for brevity). Thus, consistent with predictions from the DFT calculations, the existence of the intermediate ${ }^{16} \mathrm{O}=\mathrm{Mo}={ }^{18} \mathrm{O}$ species allows for the conclusion that the dehydrated surface molybdenum oxide species exist as surface dioxo $\mathrm{O}_{2} \mathrm{Mo}(=\mathrm{O})_{2}$ species.

The dehydrated supported $\mathrm{MoO}_{3} / \mathrm{TiO}_{x} / \mathrm{SiO}_{2}, \mathrm{MoO}_{3} / \mathrm{ZrO}_{x} / \mathrm{SiO}_{2}$, and $\mathrm{MoO}_{3} / \mathrm{AlO}_{x} /$ $\mathrm{SiO}_{2}$ catalysts give rise to Raman bands in the $985-1002 \mathrm{~cm}^{-1}$ assigned to dehydrated surface dioxo $\mathrm{Mo}(=\mathrm{O})_{2}$ species, and are presented in curves $\mathrm{A}, \mathrm{B}$, and $\mathrm{C}$, respectively, of Figure 1.6 (left) $[88,100]$. These Raman spectra do not exhibit the Raman band at $1020 \mathrm{~cm}^{-1}$ of the isolated surface monoxo $\mathrm{M}=\mathrm{O}$ species, suggesting that the surface modifiers affected the ratio of the two dehydrated surface $\mathrm{MoO}_{x}$ species. The slight shift from 981 to $985-1002 \mathrm{~cm}^{-1}$ indicates distortions of the dioxo surface $\mathrm{Mo}(=\mathrm{O})_{2}$ species from interactions with the surface $\mathrm{AlO}_{x}, \mathrm{TiO}_{x}$, and $\mathrm{ZrO}_{x}$ additives on the surface-modified $\mathrm{SiO}_{2}$ support, schematically depicted in Figure 1.6 (right). The somewhat higher wavenumber value of $1002 \mathrm{~cm}^{-1}$ for the supported $\mathrm{MoO}_{3} / \mathrm{AlO}_{x} /$ $\mathrm{SiO}_{2}$ system may reflect the presence of some monoxo surface $\mathrm{MoO}_{5}$ species. The corresponding surface dioxo $v_{\text {as }}\left(\mathrm{Mo}(=\mathrm{O})_{2}\right)$ band occurs as a shoulder at $\sim 965-975$ $\mathrm{cm}^{-1}$ on the strong symmetric stretch and is most visible for the highly distorted supported $\mathrm{MoO}_{3} / \mathrm{AlO}_{x} / \mathrm{SiO}_{2}$ catalyst at $973 \mathrm{~cm}^{-1}$, however, surface hydroxyl groups and some surface dioxo species may also overlap in this region. The weak and broad bands at $\sim 825-880 \mathrm{~cm}^{-1}$ observed for supported $\mathrm{MoO}_{3} / \mathrm{AlO}_{x} / \mathrm{SiO}_{2}$ and $\mathrm{MoO}_{3} /$ $\mathrm{ZrO}_{x} / \mathrm{SiO}_{2}$ catalysts are assigned to bridging $\mathrm{M}-\mathrm{O}-\mathrm{Al}$ and $\mathrm{M}-\mathrm{O}-\mathrm{Zr}$ bonds, respectively $[95,101,102]$. 
1.7 Molecular Structure of Dehydrated Supported $\mathrm{Re}_{2} \mathrm{O}_{7} / \mathrm{SiO}_{2} \mid 11$
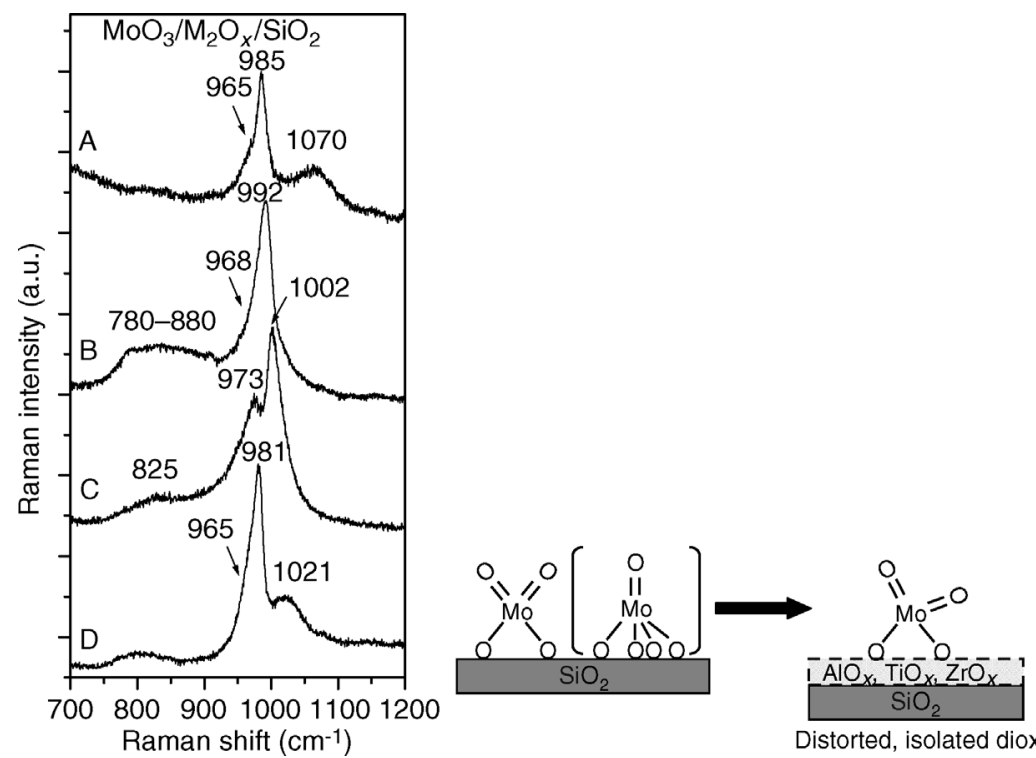

Distorted, isolated dioxo

Figure 1.6 (Left) In situ Raman spectra $(325 \mathrm{~nm})$ of dehydrated supported (A) $3 \% \mathrm{MoO}_{3} / \mathrm{TiO}_{x} / \mathrm{SiO}_{2}$, (B) $3 \% \mathrm{MoO}_{3} / \mathrm{ZrO}_{x} / \mathrm{SiO}_{2}$, (C) $3 \% \mathrm{MoO}_{3} / \mathrm{AlO}_{x} / \mathrm{SiO}_{2}$, and (D) $3 \% \mathrm{MoO}_{3} / \mathrm{SiO}_{2}$ under oxidizing conditions at $500^{\circ} \mathrm{C}$. (Right) Schematic of dehydrated supported $\mathrm{MoO}_{x}$ species on $\mathrm{SiO}_{2}$ and on surface-modified silica.

\section{7}

Molecular Structure of Dehydrated Supported $\mathrm{Re}_{2} \mathrm{O}_{7} / \mathrm{SiO}_{2}$ and $\mathrm{Re}_{2} \mathrm{O}_{7} / \mathrm{M}_{2} \mathrm{O}_{x} / \mathrm{SiO}_{2}$
Catalyst Systems

The dehydrated surface rhenium oxide species on the supported $\mathrm{Re}_{2} \mathrm{O}_{7} / \mathrm{SiO}_{2}$ catalyst are present as isolated trioxo surface $(\mathrm{O}=)_{3} \mathrm{Re}-\mathrm{O}-\mathrm{Si}$ species, giving rise to Raman bands for $v_{\mathrm{s}}\left(\operatorname{Re}(=\mathrm{O})_{3}\right)$ at $1010 \mathrm{~cm}^{-1}, v_{\text {as }}\left(\operatorname{Re}(=\mathrm{O})_{3}\right)$ at $977 \mathrm{~cm}^{-1}$, and bending $\delta(\mathrm{O}-\mathrm{Re}-\mathrm{O})$ at $343 \mathrm{~cm}^{-1}$. The Raman spectrum is presented in curve A of Figure 1.7 (left) $[103,104]$. The $977 \mathrm{~cm}^{-1}$ band from the surface $\mathrm{ReO}_{x}$ species of $\mathrm{Re}_{2} \mathrm{O}_{7} / \mathrm{SiO}_{2}$ overlaps with the $\mathrm{Si}-\mathrm{OH}$ band at $970 \mathrm{~cm}^{-1}$, as will be further shown below. The positions of these three surface $\mathrm{ReO}_{x}$ Raman bands coincide with the $v_{\mathrm{s}}\left(\operatorname{Re}(=\mathrm{O})_{3}\right)$, $v_{\text {as }}\left(\operatorname{Re}(=\mathrm{O})_{3}\right)$, and $\delta(\mathrm{O}-\mathrm{Re}-\mathrm{O})$ vibrations of the trioxo $\mathrm{Re}(=\mathrm{O})_{3}$ functionality of the gas phase $(\mathrm{O}=)_{3} \mathrm{Re}-\mathrm{O}-\mathrm{Re}(=\mathrm{O})_{3}$ molecule at 1009,972 , and $341 \mathrm{~cm}^{-1}$, respectively. However, the vibrations of the bridging $\mathrm{Re}-\mathrm{O}-\mathrm{Re}$ bond at $456\left(v_{\mathrm{s}}\right)$ and $185(\delta) \mathrm{cm}^{-1}$ are absent, and this is consistent with the isolated nature of the surface rhenia species on the $\mathrm{SiO}_{2}$ support. The bridging $\mathrm{Re}-\mathrm{O}-\mathrm{Si}$ band, expected to give rise to a weak band at $\sim 900 \mathrm{~cm}^{-1}$, is not readily apparent in the vibrational spectrum. Upon exposure to reducing hydrogen environments, the dehydrated surface $\mathrm{ReO}_{4}$ species on $\mathrm{SiO}_{2}$ readily reduces, as shown in curve $\mathrm{C}$ of Figure 1.7 (left). The complete removal of the $\mathrm{Re}-\mathrm{O}$ vibrations under reducing environments followed by complete restoration of 
$12 \mid 1$ Use of Oxide Ligands in Designing Catalytic Active Sites

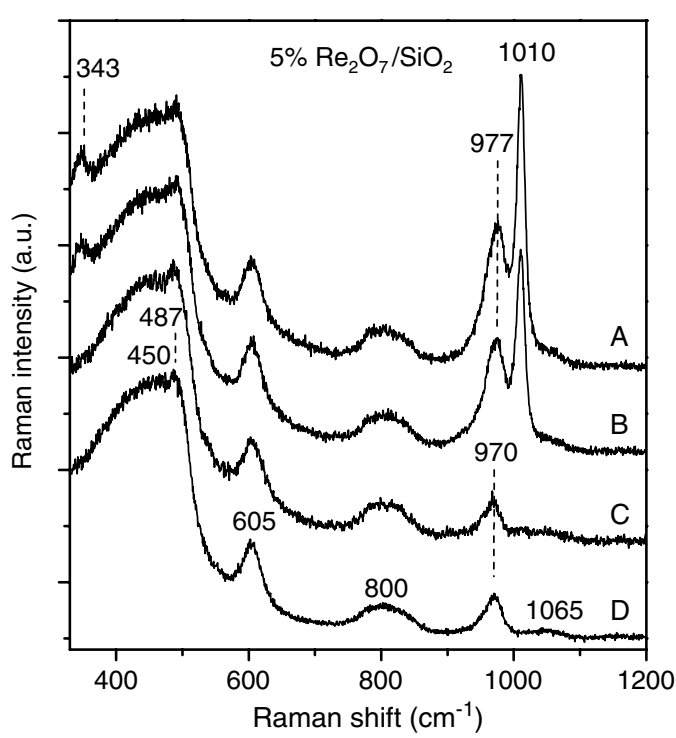

Figure 1.7 (Left) In situ Raman spectra $(325 \mathrm{~nm})$ of supported $5 \% \mathrm{Re}_{2} \mathrm{O}_{7} / \mathrm{SiO}_{2}$ under $(\mathrm{A})$ oxygen environment at $450{ }^{\circ} \mathrm{C}$, (B) reoxidation after hydrogen reduction at $2 \% \mathrm{H}_{2} / \mathrm{Ar}$, and (C) after 40 min $\mathrm{H}_{2}$ exposure. The $\mathrm{SiO}_{2}$ support material is shown as reference (D). Reproduced from Ref. [55]. (Right) Time-resolved in situ Raman

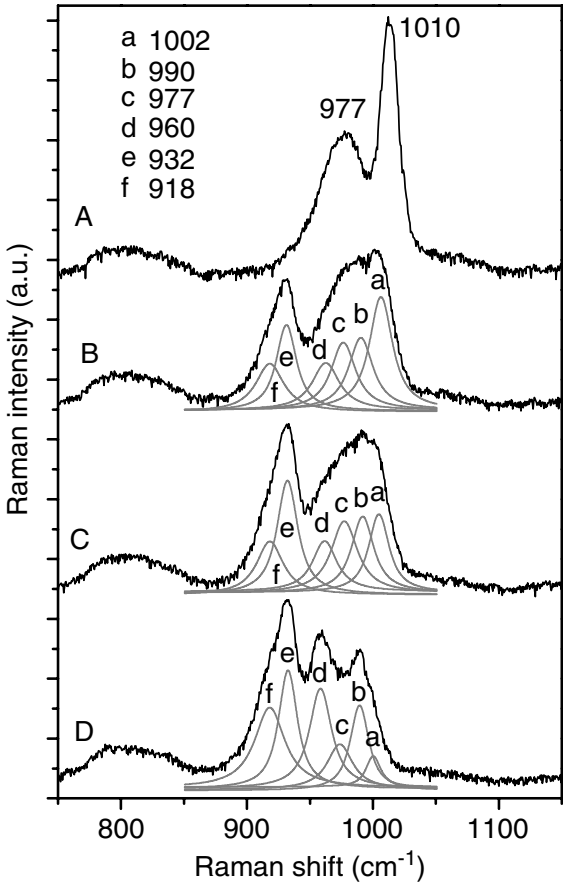

spectra of supported $5 \% \mathrm{Re}_{2} \mathrm{O}_{7} / \mathrm{SiO}_{2}$ under $\mathrm{H}_{2}{ }^{18} \mathrm{O}$ exposure after (A) 0 min, (B) $34 \mathrm{~min},(C)$ $51 \mathrm{~min}$, and (D) $123 \mathrm{~min}$. The Raman spectra deconvolution are shown in gray and labeled with small letters, with the lower-case letters $a, b, c, d$, $\mathrm{e}$, and $\mathrm{f}$ referring to specific band positions indicated in the figure.

the $\mathrm{Re}-\mathrm{O}$ vibrations under oxidizing environments (Raman bands at 1010, 977, and $343 \mathrm{~cm}^{-1}$ ) in curve B of Figure 1.7 (left) confirms that these vibrations are associated with the surface rhenia species. Note that the Raman spectrum of the reduced supported $\mathrm{Re}_{2} \mathrm{O}_{7} / \mathrm{SiO}_{2}$ catalyst looks exactly like the Raman spectrum of the dehydrated $\mathrm{SiO}_{2}$ support and demonstrates that the $\mathrm{SiO}_{2}$ support is not reduced by the reduction treatments. In addition, the broadening of the $977 \mathrm{~cm}^{-1}$ band to $968 \mathrm{~cm}^{-1}$ and the lack of shift of the 343 and $1010 \mathrm{~cm}^{-1}$ Raman bands during exposure to $\mathrm{D}_{2} \mathrm{O}$ reflect that these vibrations are not associated with surface $\mathrm{Re}-\mathrm{OH}$ species [55].

Isotopic $\mathrm{H}_{2}{ }^{18} \mathrm{O}$ exchange of the dehydrated supported $\mathrm{Re}_{2} \mathrm{O}_{7} / \mathrm{SiO}_{2}$ catalyst is shown in Figure 1.7 (right) and reveals the Raman band splitting of the $\mathrm{Re}(=\mathrm{O})_{3}$ species. The initial $v_{\mathrm{s}}\left(\operatorname{Re}\left(={ }^{16} \mathrm{O}\right)_{3}\right)$ Raman band at $1010 \mathrm{~cm}^{-1}$ rapidly decreases in intensity and shifts to lower wavenumbers because of the incorporation of ${ }^{18} \mathrm{O}$ into the surface $\mathrm{ReO}_{4}$ species and, concurrently, the $v_{\text {as }}\left(\operatorname{Re}\left(={ }^{16} \mathrm{O}\right)_{3}\right)$ band at $977 \mathrm{~cm}^{-1}$ also shifts to lower wavenumbers. The associated bending $\delta\left({ }^{16} \mathrm{O}-\mathrm{Re}-{ }^{16} \mathrm{O}\right)$ mode shifts from 343 to $\sim 335 \mathrm{~cm}^{-1}$ as a consequence of incorporation of the ${ }^{18} \mathrm{O}$ into the surface rhenia structure [56]. The time-resolved Raman spectroscopy during the isotopic oxygen 
exchange allows for the resolution of the multiple band splitting of the symmetric and asymmetric vibrations, where the $v_{\mathrm{s}}$ vibrations are deconvoluted at $\sim 1002,990$, and $\sim 960 \mathrm{~cm}^{-1}$ and the $v_{\text {as }}$ vibrations are deconvoluted at $932 \mathrm{~cm}^{-1}$, with a small shoulder at $\sim 918 \mathrm{~cm}^{-1}$. The Raman bands at $\sim 1002$ and $990 \mathrm{~cm}^{-1}$ are tentatively assigned to a single substituted- ${ }^{18} \mathrm{O}$ species, ${ }^{18} \mathrm{O}=\operatorname{Re}\left(={ }^{16} \mathrm{O}\right)_{2}$, and a double substituted- ${ }^{18} \mathrm{O}$ species, $\left({ }^{18} \mathrm{O}=\right)_{2} \mathrm{Re}={ }^{16} \mathrm{O}$, where the $990 \mathrm{~cm}^{-1}$ band grows at the expense of $1002 \mathrm{~cm}^{-1}$. Furthermore, the $960 \mathrm{~cm}^{-1}$ vibration, which becomes distinct after prolonged exposure to isotopic oxygen and at the expense of the $\sim 1002$ and $990 \mathrm{~cm}^{-1}$ bands, is tentatively attributed to the triple substituted- ${ }^{18} \mathrm{O}$ species, $\left({ }^{18} \mathrm{O}=\right){ }_{3}$ Re. It is expected that if complete isotopic oxygen exchange were achieved beyond what is presented in curve D of Figure 1.7 (right), the $990 \mathrm{~cm}^{-1}$ would completely disappear and bereplaced with the triply substituted $\left({ }^{18} \mathrm{O}=\right)_{3} \operatorname{Re}$ band at $960 \mathrm{~cm}^{-1}$. For the initial $v_{\text {as }}\left(\operatorname{Re}\left(={ }^{16} \mathrm{O}\right)_{3}\right)$ band at $977 \mathrm{~cm}^{-1}$, isotopic exchange shifts the band to $932 \mathrm{~cm}^{-1}$ and a shoulder at $918 \mathrm{~cm}^{-1}$, where both vibrations are tentatively assigned to a fully exchanged $v_{\mathrm{as}}(\mathrm{Re}$ $\left.\left(={ }^{18} \mathrm{O}\right)_{3}\right)$ vibration with various degrees of distortion. The detection of four surface rhenia isotopic vibrations $\left(\operatorname{Re}\left(={ }^{16} \mathrm{O}\right)_{3}\right.$ at $1010 \mathrm{~cm}^{-1}, \operatorname{Re}\left(={ }^{18} \mathrm{O}\right)\left(={ }^{16} \mathrm{O}\right)_{2}$ at $\sim 1002$ $\mathrm{cm}^{-1}, \operatorname{Re}\left(={ }^{18} \mathrm{O}\right)_{2}\left(={ }^{16} \mathrm{O}\right)$ at $990 \mathrm{~cm}^{-1}$, and $\operatorname{Re}\left(={ }^{18} \mathrm{O}\right)_{3}$ at $\left.960 \mathrm{~cm}^{-1}\right)$ is consistent with the trioxo structure of the dehydrated surface $\mathrm{ReO}_{4}$ species on $\mathrm{SiO}_{2}$.

The in situ Raman spectra of the dehydrated supported $\mathrm{Re}_{2} \mathrm{O}_{7} / \mathrm{TiO}_{x} / \mathrm{SiO}_{2}$, $\mathrm{Re}_{2} \mathrm{O}_{7} / \mathrm{ZrO}_{x} / \mathrm{SiO}_{2}$, and $\mathrm{Re}_{2} \mathrm{O}_{7} / \mathrm{AlO}_{x} / \mathrm{SiO}_{2}$ catalysts are presented in Figure 1.8

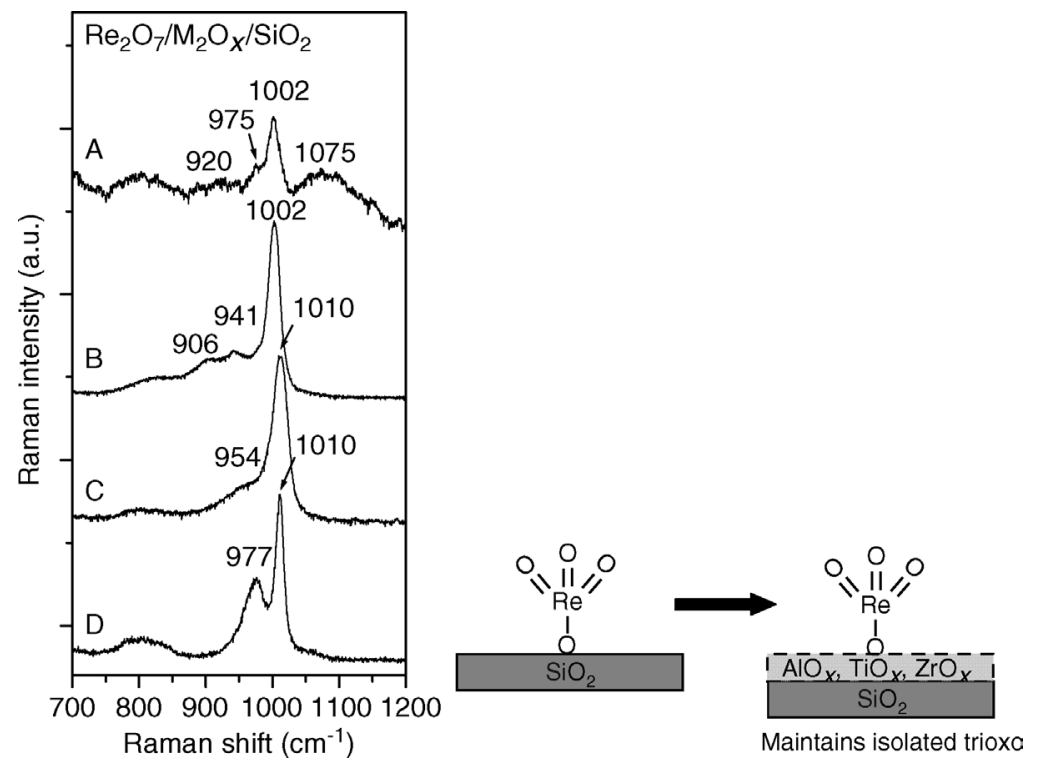

Figure 1.8 (Left) In situ Raman spectra $(325 \mathrm{~nm})$ of dehydrated supported (A) $3 \% \mathrm{Re}_{2} \mathrm{O}_{7} / \mathrm{TiO}_{x} / \mathrm{SiO}_{2}$, (B) $3 \% \mathrm{Re}_{2} \mathrm{O}_{7} / \mathrm{ZrO}_{x} / \mathrm{SiO}_{2}$, (C) $3 \% \mathrm{Re}_{2} \mathrm{O}_{7} / \mathrm{AlO}_{x} / \mathrm{SiO}_{2}$, and (D) $3 \% \mathrm{Re}_{2} \mathrm{O}_{7} / \mathrm{SiO}_{2}(532 \mathrm{~nm}$ for $3 \% \mathrm{Re}_{2} \mathrm{O}_{7} / \mathrm{TiO}_{x} / \mathrm{SiO}_{2}$ only) under oxidizing conditions at $450^{\circ} \mathrm{C}$. (Right) Schematic of dehydrated supported $\mathrm{ReO}_{x}$ species on $\mathrm{SiO}_{2}$ and on surface-modified silica. 
(left) and give rise to strong bands at $\sim 1002-1010 \mathrm{~cm}^{-1}$ that is characteristic of the trioxo $v_{\mathrm{s}}\left(\mathrm{Re}(=\mathrm{O})_{3}\right)$ functionality [88]. The corresponding asymmetric stretch appears between 941 and $975 \mathrm{~cm}^{-1}$ for the surface-modified $\mathrm{SiO}_{2}$ catalysts. The bridging $\mathrm{Re}-\mathrm{O}-\mathrm{Ti}$ and $\mathrm{Re}-\mathrm{O}-\mathrm{Zr}$ vibrations are also observable at $\sim 905-920$ $\mathrm{cm}^{-1}$. The similar band positions of the $v_{\mathrm{s}}$ and $v_{\mathrm{as}}\left(\operatorname{Re}(=\mathrm{O})_{3}\right)$ and bending mode of the model and surface-modified supported rhenia catalysts show that the surface oxide additives do not significantly alter the structure of the dehydrated surface $\mathrm{ReO}_{x}$ species that consists of the terminal trioxo $\mathrm{Re}(=\mathrm{O})_{3}$ functionality (see schematic in Figure 1.8 (right)).

\section{8}

\section{Electronic Structure of Dehydrated Supported $\mathrm{MO}_{x} / \mathrm{SiO}_{2}$ and $\mathrm{M}_{1} \mathrm{O}_{x} / \mathrm{M}_{2} \mathrm{O}_{x} / \mathrm{SiO}_{2}$ Catalysts via In Situ UV-Vis Spectroscopy}

The corresponding UV-Vis DRS complements the surface Raman and IR spectroscopic vibrational information and provided local structural information (isolated monomer, dimer, polymeric chain, cluster, or 3D structure) of the supported metal oxide species. UV-Vis DRS monitors the surface metal oxide cation electronic structure via the ligand-to-metal charge transfer (LMCT) band position and the corresponding edge energy $\left(E_{\mathrm{g}}\right)$ value. The $E_{\mathrm{g}}$ values of the surface metal oxide species are determined by comparison against the electronic structures of welldefined metal oxide reference compounds [105-107]. In addition, each supported $\mathrm{MO}_{x} / \mathrm{SiO}_{2}$ catalyst system possesses unique spectral signatures through the LMCT band maxima that provide additional insights into their local molecular structures. It should be noted that the absorbance of a strong $\mathrm{M}_{2} \mathrm{O}_{x}$ species, such as $\mathrm{TiO}_{x}$ for surface-modified $\mathrm{TiO}_{x} / \mathrm{SiO}_{2}$, may strongly overlap the contribution of the $\mathrm{M}_{1} \mathrm{O}_{x}$ species, such as the $\mathrm{Re}_{2} \mathrm{O}_{7} / \mathrm{TiO}_{x} / \mathrm{SiO}_{2}$. Therefore, careful baseline subtraction must be performed to ensure proper band deconvolution. The in situ UV-Vis $E_{\mathrm{g}}$ values for the dehydrated surface $\mathrm{M}_{1} \mathrm{O}_{x}\left(\mathrm{M}_{1}=\mathrm{V}\right.$, Mo, and Re) species on native $\mathrm{SiO}_{2}$ and surface-modified $\mathrm{SiO}_{2}$ catalyst samples are scaled against well-defined reference compounds in Figure 1.9.

The dehydrated model supported $\mathrm{M}_{1} \mathrm{O}_{x} / \mathrm{SiO}_{2}$ catalysts predominantly exist as isolated surface $\mathrm{MO}_{x}$ species on $\mathrm{SiO}_{2}$, which is reflected by the relatively high UV-Vis $E_{g}$ values in Figure 1.9. The addition of the surface modifiers retains the high $E_{\mathrm{g}}$ values. For the surface molybdena catalyst system, the introduction of the surface $\mathrm{M}_{2} \mathrm{O}_{x}$ modifiers eliminates the higher wavenumber, or lower energy, LMCT transition in the UV-Vis spectra for the surface $\mathrm{M}_{1} \mathrm{O}_{x}$ species, which suggests a more isolated or distorted surface molybdena species [88]. This is in agreement with the Raman observations of the distortions of the surface $\mathrm{MoO}_{x}$ species in supported $\mathrm{MoO}_{x} / \mathrm{M}_{2} \mathrm{O}_{x} / \mathrm{SiO}_{2}$ catalysts and the suppression of the surface monoxo species. The lack of influence of the different surface $\mathrm{M}_{2} \mathrm{O}_{x}$ ligands on the dehydrated surface $\mathrm{O}_{3} \mathrm{~V}=\mathrm{O}$ and $\mathrm{ORe}(=\mathrm{O})_{3}$ species reveals that these structures are not perturbed by the surface modification of the $\mathrm{SiO}_{2}$ support. 
(a)

Polymeric $\mathrm{VO}_{6} / \mathrm{VO}_{4} \quad \mathrm{~V}_{2} \mathrm{O}_{5} / \mathrm{SiO}_{2}$ and $\mathrm{V}_{2} \mathrm{O}_{5} / \mathrm{MO}_{x} / \mathrm{SiO}_{2}$

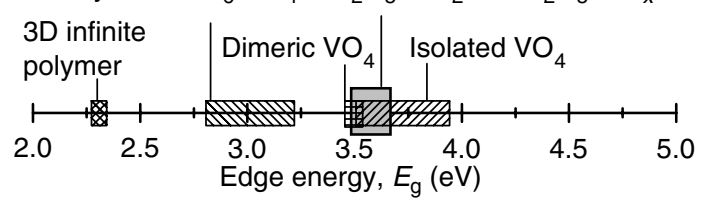

(b)

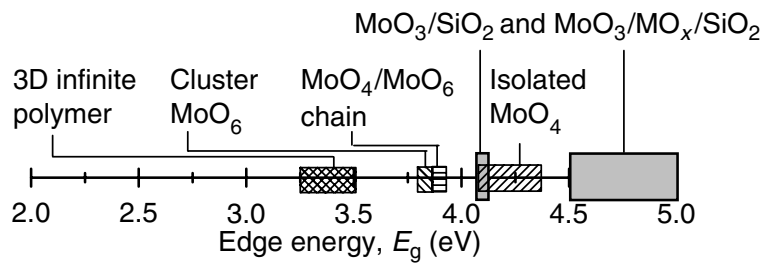

(c)

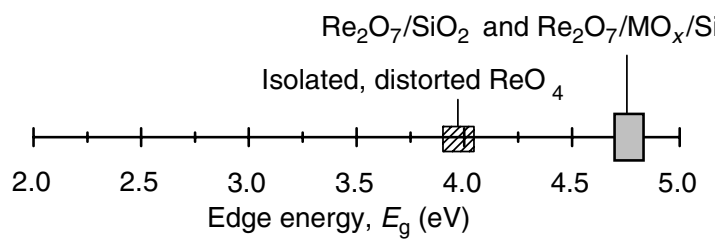

Figure 1.9 UV-Vis DRS edge energy, $E_{\mathrm{g}}$, scale for well-defined reference compounds and measured $E_{\mathrm{g}}$ values for dehydrated $\mathrm{SiO}_{2}$-supported (A) $\mathrm{VO}_{x}$ [108-114], (B) $\mathrm{MoO}_{x}$ [115-120], and (C) $\operatorname{ReO}_{x}[115,121-124]$ catalysts.

\section{9}

\section{Determination of Surface Kinetic Parameters}

The surface chemistry and reactivity of model supported $\mathrm{MO}_{x} / \mathrm{SiO}_{2}$ and $\mathrm{M}_{1} \mathrm{O}_{x} /$ $\mathrm{M}_{2} \mathrm{O}_{x} / \mathrm{SiO}_{2}$ catalysts can be determined by $\mathrm{CH}_{3} \mathrm{OH}$-TPSR spectroscopy since $\mathrm{CH}_{3} \mathrm{OH}$ is a "smart" chemical probe molecule capable of distinguishing between surface acidic, redox, and basic sites [125]. By determining the nature of the catalytic active sites (redox, acidic, or basic), their specific surface reactivity $\left(k_{\mathrm{rds}}\right)$ toward methanol can be calculated, where $k_{\text {rds }}$ represents the first-order kinetic constant of the rate-determining step (rds) [125-128]. The dissociative chemisorption of methanol forms surface methoxy $\left(\mathrm{CH}_{3} \mathrm{O}^{*}\right)$ intermediate species, which is the most abundant reaction intermediate (MARI) [129, 130], and undergoes different reaction pathways that are dependent on the nature of the catalytic active site: formaldehyde (HCHO) from surface redox sites, dimethyl ether $\left(\mathrm{CH}_{3} \mathrm{OCH}_{3}, \mathrm{DME}\right)$ from surface acidic sites, and $\mathrm{CO} / \mathrm{CO}_{2}$ from surface basic sites $[125,131] . \mathrm{H}_{2} \mathrm{O}$ formation is also a product of the $\mathrm{CH}_{3} \mathrm{OH}$ surface chemistry. For the purposes of a focused discussion in this chapter, only the redox surface reactivity arising from methanol oxidative dehydrogenation to formaldehyde will be elaborated upon henceforth.

The surface kinetic parameters $\left(E_{\text {act }}\right.$ and $\left.k_{\text {rds }}\right)$ for the surface methoxy reactions to $\mathrm{HCHO}$ are directly obtained from the $\mathrm{CH}_{3} \mathrm{OH}$-TPSR spectra. The rds for the 
unimolecular surface $\mathrm{CH}_{3} \mathrm{O}^{*}$ dehydrogenation to $\mathrm{HCHO}$ involves breaking of the surface methoxy $\mathrm{C}-\mathrm{H}$ bond [34]. Applying the first-order Redhead equation [132] for the unimolecular decomposition reaction of the rds for the different reaction pathways allows for the determination of the $E_{\text {act }}$ for the surface reactions:

$$
\frac{E_{\mathrm{act}}}{R T_{\mathrm{p}}^{2}}=\left(\frac{v}{\beta}\right) \exp \left(\frac{-E_{\mathrm{act}}}{R T_{\mathrm{p}}}\right)
$$

in which $T_{\mathrm{p}}$ is the $\mathrm{CH}_{3} \mathrm{OH}$-TPSR peak temperature of the reaction product, $R$ is the gas constant $\left(1.987 \mathrm{cal} \mathrm{mol}^{-1} \mathrm{~K}^{-1}\right), v=10^{13} \mathrm{~s}^{-1}$ for first-order kinetics, and $\beta$ is the heating rate $\left(10^{\circ} \mathrm{C} \mathrm{min}^{-1}\right)$. The rate-determining step, $k_{\mathrm{rds}}$ (HCHO), for the conversion of the surface methoxy intermediate to $\mathrm{HCHO}$ is also a function of $E_{\text {act }}$ (and hence $T_{\mathrm{p}}$ ) and is determined by

$$
k_{\mathrm{rds}}=v \exp \left(\frac{-E_{\mathrm{act}}}{R T}\right)
$$

in which $T$ is the reference temperature $\left(T=230^{\circ} \mathrm{C}\right)$ that will be used for comparison of $k_{\text {rds }}$ values.

\subsection{0}

\section{Redox Surface Reactivity of Model Supported $\mathrm{M}_{1} \mathrm{O}_{x} / \mathrm{SiO}_{2}$ Catalysts}

The specific catalytic activities $\left(k_{\mathrm{rds}}\right)$ for the formation of HCHO of the model supported $\mathrm{M}_{1} \mathrm{O}_{x} / \mathrm{SiO}_{2}$ and surface-modified $\mathrm{M}_{2} \mathrm{O}_{x} / \mathrm{SiO}_{2}$ catalysts were determined with $\mathrm{CH}_{3} \mathrm{OH}$-TPSR and are compared to their corresponding unsupported bulk $\mathrm{MO}_{x}$ catalysts in Figures 1.10. The surface reactivity of the model silica-supported $\mathrm{M}_{1} \mathrm{O}_{x}$ catalytic active sites is affected by anchoring of the $\mathrm{M}_{1} \mathrm{O}_{x}$ transition metal oxides to the $\mathrm{SiO}_{2}$ support. The specific activity of the surface $\mathrm{M}_{1} \mathrm{O}_{x}\left(\mathrm{M}_{1}=\mathrm{V}\right.$ or Mo) catalytic active sites on $\mathrm{SiO}_{2}$ is generally lower, by several orders of magnitude, than that of their unsupported $\mathrm{M}_{1} \mathrm{O}_{x}$ metal oxides. The same is also true for the supported $\mathrm{ZrO}_{x}$ species on $\mathrm{SiO}_{2}$. Whereas the surface $\mathrm{AlO}_{x}$ on silica is not affected by its anchoring to the $\mathrm{SiO}_{2}$ support, with both exhibiting no redox activity, the surface $\mathrm{TiO}_{x}$ species on $\mathrm{SiO}_{2}$ possess redox behavior while bulk $\mathrm{TiO}_{2}$ does not exhibit redox characteristics. These differences reflect the changes resulting from anchoring isolated surface $\mathrm{MO}_{x}$ species onto the $\mathrm{SiO}_{2}$ support surface via the bridging $\mathrm{M}-\mathrm{O}-\mathrm{Si}$ linkages. Although some contribution may come from the different molecular structures present in the bulk and supported $\mathrm{MO}_{x}$ catalysts, the coordination of the surface $\mathrm{M}_{1} \mathrm{O}_{x}$ and $\mathrm{M}_{2} \mathrm{O}_{x}$ species to the silica support appears to be the major influence on the reactivity characteristics of the surface oxide anchored to the $\mathrm{SiO}_{2}$ support.

\subsection{1}

\section{Redox Surface Reactivity of Supported $\mathrm{M}_{1} \mathrm{O}_{x} / \mathrm{M}_{2} \mathrm{O}_{x} / \mathrm{SiO}_{2}$ Catalysts}

The introduction of the surface $\mathrm{AlO}_{x}, \mathrm{TiO}_{x}$, and $\mathrm{ZrO}_{x}$ modifiers onto the $\mathrm{SiO}_{2}$ support dramatically enhances the $k_{\text {rds }}$ redox values, by as much as a factor of $\sim 10^{4}$, of the 


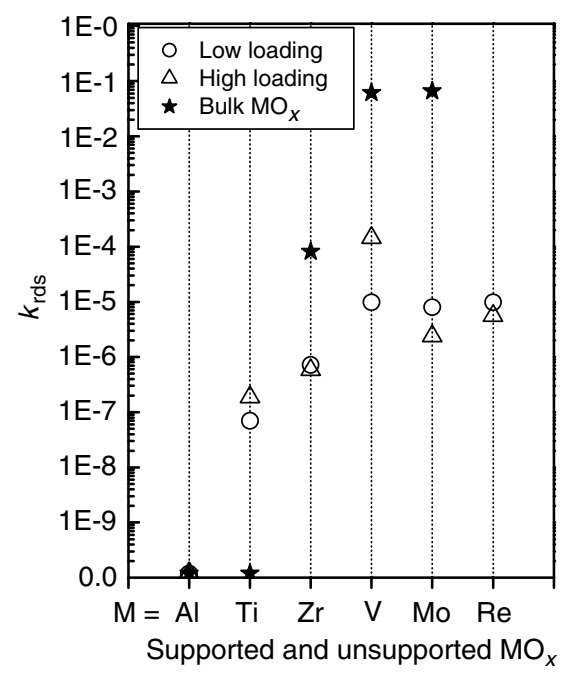

Figure 1.10 The $k_{\text {rds }}$ values for $\mathrm{HCHO}$ formation from supported $\mathrm{M}_{1} \mathrm{O}_{x} / \mathrm{SiO}_{2}$ and $\mathrm{M}_{2} \mathrm{O}_{x} / \mathrm{SiO}_{2}$ catalysts at $230^{\circ} \mathrm{C}$ for low and high (maximum dispersion) metal oxide coverage. The $k_{\text {rds }}$ values of the unsupported bulk oxides are also shown for reference (with the star notation) [125-128].

supported $\mathrm{M}_{1} \mathrm{O}_{x}$ catalytic active sites, as presented in Figure 1.11. These results are in agreement with steady-state $\mathrm{CH}_{3} \mathrm{OH}$ oxidation studies, where the turnover frequency (TOF) significantly increases with the addition of the surface modifiers for the supported $\mathrm{M}_{1} \mathrm{O}_{x} / \mathrm{M}_{2} \mathrm{O}_{x} / \mathrm{SiO}_{2}$ catalyst systems.

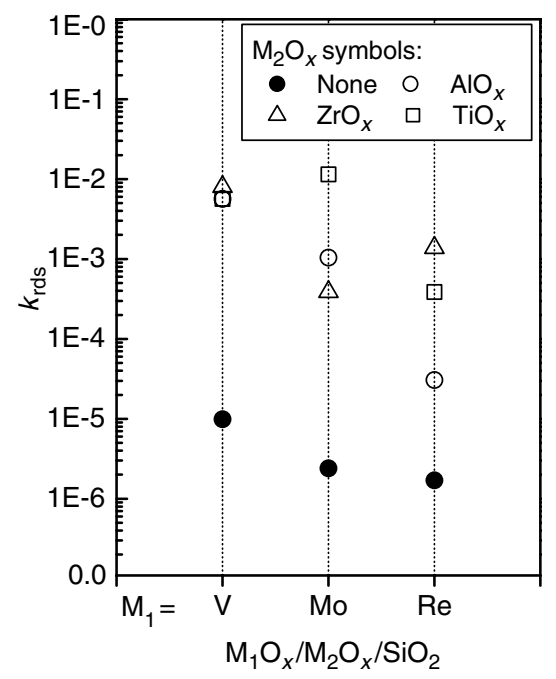

Figure 1.11 The $k_{\text {rds }}$ values for supported $3 \% \mathrm{M}_{1} \mathrm{O}_{x} / 5 \% \mathrm{M}_{2} \mathrm{O}_{x} /$

$\mathrm{SiO}_{2}$ catalysts $\left(\mathrm{M}_{1}=\mathrm{V}, \mathrm{Mo}\right.$, and $\mathrm{Re} ; \mathrm{M}_{2}=\mathrm{Al}, \mathrm{Zr}$, and Ti) for decomposition of surface methoxy intermediate to $\mathrm{HCHO}$. 
Combining the molecular structural information with the corresponding reactivity studies allows for examination of possible molecular/electronic structure-activity relationships for the group 5-7 supported $\mathrm{M}_{1} \mathrm{O}_{x}$ active sites. The multilayered supported $\mathrm{VO}_{x} / \mathrm{M}_{2} \mathrm{O}_{x} / \mathrm{SiO}_{2}$ and $\mathrm{ReO}_{x} / \mathrm{M}_{2} \mathrm{O}_{x} / \mathrm{SiO}_{2}$ catalyst systems contain the same surface monoxo $\mathrm{VO}_{4}$ and trioxo $\mathrm{ReO}_{4}$ structures, respectively, as their $\mathrm{M}_{1} \mathrm{O}_{x} / \mathrm{SiO}_{2}$ counterparts. Consequently, the difference in reactivity is not related to a structural change of the surface $\mathrm{M}_{1} \mathrm{O}_{x}$ species but is due to the different support ligands $\left(\mathrm{M}_{2} \mathrm{O}_{x}\right.$ and $\mathrm{SiO}_{2}$ ). It is proposed that the enhanced surface redox activity is most likely related to the lower electronegativity of substrate oxide cations $(\mathrm{Si}>\mathrm{Al}>\mathrm{Ti} \sim \mathrm{Zr}$ ). Lowering of the oxide support ligand electronegativity increases the electron density on the oxygen of the bridging $\mathrm{M}_{1} \mathrm{O}_{x}-\mathrm{O}-\mathrm{M}_{2} \mathrm{O}_{x}$ bond, which facilitates the disssociative chemisorption of methanol and decomposition of the surface methoxy intermediate to HCHO [133]. Several recent theoretical DFT/ab initio calculations have concluded that for the supported vanadia catalytic systems, the bridging $\mathrm{V}-\mathrm{O}-$ support bond is the most energetically favorable methanol chemisorption site on the surface $\mathrm{VO}_{x}$ structure $[84,85,134]$. The bridging $\mathrm{V}-\mathrm{O}$-support bond has been shown to dramatically affect the steady-state TOF, defined as the number of $\mathrm{HCHO}$ molecules formed per surface $\mathrm{VO}_{x}$ sites per second [135] during steady-state $\mathrm{CH}_{3} \mathrm{OH}$ oxidation. The TOF increases by two orders of magnitude with different supports, from $10^{-3}$ to $10^{-1} \mathrm{~s}^{-1}\left(\mathrm{SiO}_{2} \ll \mathrm{Al}_{2} \mathrm{O}_{3} \ll \mathrm{TiO}_{2}<\mathrm{ZrO}_{2}\right)$. Therefore, by substituting the bulk $\mathrm{SiO}_{2}$ support with oxide ligands of lower electronegativity, the activity of the surfacemodified vanadia catalyst systems was enhanced due to the formation of the bridging $\mathrm{V}-\mathrm{O}-\mathrm{Al}, \mathrm{V}-\mathrm{O}-\mathrm{Zr}$, and $\mathrm{V}-\mathrm{O}-\mathrm{Ti}$ bonds, which are the favorable active sites for methanol chemisorption. In addition, anchoring of the surface $\mathrm{M}_{1} \mathrm{O}_{x}$ species onto the surface $\mathrm{M}_{2} \mathrm{O}_{x}$ species may also change their local molecular structures and their related surface reactivity properties.

\subsection{2}

\section{Conclusions}

It is shown in this chapter that the activity of the supported catalytic active sites can be controlled and designed by oxide ligands. The molecular and electronic characterization of the model supported $\mathrm{MO}_{x} / \mathrm{SiO}_{2}$ and surface-modified supported $\mathrm{M}_{1} \mathrm{O}_{x} / \mathrm{M}_{2} \mathrm{O}_{x} /$ $\mathrm{SiO}_{2}$ catalyst systems were determined by in situ Raman and UV-Vis spectroscopy, respectively. The in situ Raman spectroscopy measurements were undertaken using various new approaches, such as time-resolved spectroscopy under reductive $\left(\mathrm{H}_{2}\right)$ and isotopic exchange $\left({ }^{18} \mathrm{O}-{ }^{16} \mathrm{O}\right.$ and $\left.\mathrm{D}_{2} \mathrm{O}-\mathrm{H}_{2} \mathrm{O}\right)$ environments. These new findings revealed that supported $\mathrm{V}_{2} \mathrm{O}_{5} / \mathrm{SiO}_{2}$ system contains isolated monoxo $\mathrm{V}=\mathrm{O}$ surface species, supported $\mathrm{MoO}_{3} / \mathrm{SiO}_{2}$ consists of both isolated monoxo $\mathrm{M}=\mathrm{O}$ and dioxo $\mathrm{O}=\mathrm{Mo}=\mathrm{O}$ surface species, and supported $\mathrm{Re}_{2} \mathrm{O}_{7} / \mathrm{SiO}_{2}$ possesses isolated trioxo $\mathrm{Re}$ $(=\mathrm{O})_{3}$ surface species. The redox activity of these surface $\mathrm{M}_{1} \mathrm{O}_{x}$ species is significantly reduced by their anchoring to the $\mathrm{SiO}_{2}$ support. The oxide ligands of the surfacemodified $\mathrm{SiO}_{2}$ catalysts, on the other hand, did not significantly alter the molecular structures of the model systems, but did significantly increase the catalytic redox 
reactivity performance by as much as a factor of $\sim 10^{4}$. This enhancement in redox surface activity is through the bridging $\mathrm{M}-\mathrm{O}$-support bonds and their relative electronegativity. The lower cation electronegativity values of the $\mathrm{M}_{2} \mathrm{O}_{x}$ oxide ligands increase the electron density of the oxygen atom in the bridging $\mathrm{M}_{1} \mathrm{O}_{x}-\mathrm{O}-\mathrm{M}_{2} \mathrm{O}_{x}$ and, consequently, enhance its proton-accepting characteristics $\left(\mathrm{CH}_{3} \mathrm{O}-\mathrm{H}\right.$ during chemisorption and ${ }^{*} \mathrm{OCH}_{2}-\mathrm{H}$ during the surface decomposition step).

\section{Acknowledgments}

The authors gratefully acknowledge the support from the United States Department of Energy - Basic Energy Sciences grant DEFG02-93ER14350.

\section{References}

1 McDaniel, M.P. (1985) Advances in Catalysis, 33, 47.

2 Burwell, R.L., Haller, G.L., Taylor, K.C. and Read, J.F. (1969) Advancesin Catalysis, 20, 1.

3 Mol, J.C. and Mouljin, J.A. (1987) Catalysis - Science and Technology, Vol. 8 (eds J.R. Anderson and M. Boudart), Springer-Verlag, Berlin, p. 69.

4 Grzybowska-Swierkosz, B. and Haber, J. (1984) Vanadia Catalysts for Processes of Oxidation of Aromatic Hydrocarbons, Polish Scientific Publications, Warsaw.

5 Bosch, J. and Jansen, F. (1988) Catalysis Today, 2, 369.

6 Knozinger, H. (1989) Proceedings of the 9th International Congress Catalysis, Calgary, Vol. 5 (eds. M.J. Phillips and M. Ternan), The Chemical Institute of Canada, Ottawa, p. 20.

7 Prins, R., de Beer, V.H.J. and Somorjai, G.A. (1989) Catalysis Reviews Science and Engineering, 31, 1.

8 Hall, W.K. (1986) Chemistry and Physics of Solid Surfaces (eds. R. Vanselow and R.F. Howe), Springer-Verlag, Berlin, p. 73.

9 Topsoe, H. (1983) Surface Properties and Catalysis by Non-Metals (eds. J.P. Bonnelle, B. Delmon and E. Derouane), Reidel, Dordrecht, p. 329.

10 Delmon, B. (1979) Proceedings of the 3rd International Conference on Chemistry and Uses of Molybdenum (eds. H.F. Barry and P.C.H. Mitchell), Climax Molybdenum Company, Ann Arbor, MI, p. 73.

11 Gates, B.C., Katzer, J.R. and Schuit, G.C.A. (1979) Chemistry of Catalytic Processes (eds. R. Ciofallo, J. Marschall and B. Leap), McGraw-Hill, New York, p. 390.

12 Wachs, I.E., Saleh, R.Y., Chan, S.S. and Chersich, C.C. (1985) Applied Catalysis A: General, 15, 339.

13 Grabowski, R., Grzybowska, B., Haber, J. and Sloczynski, J. (1975) Reaction Kinetics and Catalysis Letters, 2, 81.

14 Deo, G. and Wachs, I.E. (1994) Journal of Catalysis, 146, 323.

15 Mariscal, R., Galan-Fereres, M., Anderson, J.A., Alemany, L.J., Palacios, J.M. and Fierro, J.L.G. (1995) Environmental Catalysis (eds G. Centi et al.), SCI, Rome, p. 223.

16 Amiridis, M.D. and Solar, J.P. (1996) Industrial \& Engineering Chemistry Research, 35, 978.

17 Wauthoz, P., Machej, T. and Grange, P. (1991) Applied Catalysis A: General, 69, 149.

18 Vogt, E.T.C., Boot, A., van Dillen, A.J., Geus, J.W., Janssen, F.J.J.G. and van den Kerkhof, F.M.G. (1988) Journal of Catalysis, 114, 313. 
$20 \mid 1$ Use of Oxide Ligands in Designing Catalytic Active Sites

19 Galan-Fereres, M., Mariscal, R., Alemany, L.J. and Fierro, J.L.G. (1994) Journal of the Chemical Society, Faraday Transactions, 90, 3711.

20 De Boer, M., Van Dillen, A.J., Koningsberger, D.C., Geus, J.W., Vuurman, M.A. and Wachs, I.E. (1991) Catalysis Letters, 11, 227.

21 Spencer, N.D., Pereira, C.J. and Grasselli, R.K. (1990) Journal of Catalysis, 126, 546.

22 Banares, M.A., Fierro, J.L.G. and Moffat, J.B. (1993) Journal of Catalysis, 142, 406.

23 Mel, J.C. and Moulijn, J.A. (1987) Catalysis: Science and Technology, Vol. 8 (eds. J.R. Anderson and M. Boudart), Springer-Verlag, Berlin, p. 69.

24 Xiaoding, X., Boelhouwer, C., Vonk, D., Benecke, J.I. and Mol, J.C. (1986) Journal of Molecular Catalysis, 36, 47.

25 Banks, R.L. (1984) Olefin Metathesis: Technology and Application. Applied Industrial Catalysis (ed. B.E. Leach), Academic Press, New York, p. 215.

26 Haukka, S., Lakomaa, E. and Root, A. (1993) The Journal of Physical Chemistry, 97, 5085.

27 Morrow, B.A. and Mcfarlan, A.J. (1990) Journal of Non-Crystalline Solids, 120, 61.

28 Klaas, J., Schulz-Ekloff, G. and Jaeger, N.I. (1997) The Journal of Physical Chemistry. B, 101, 1305.

29 Yoshida, S., Takenaka, S., Tanaka, T., Hirano, H. and Hayashi, H. (1996) Eleventh International Congress on Catalysis, Studies in Surface Science and Catalysis, 101, 871.

30 Srinivasan, S., Datye, A.K., Hampden-Smith, M., Wachs, I.E., Deo, G., Jehng, J.M., Turek, A.M. and Peden, C.H.F. (1991) Journal of Catalysis, 131, 260.

31 Srinivasan, S., Datye, A.K., Smith, M.H. and Peden, C.H.F. (1994) Journal of Catalysis, 145, 565.

32 Deo, G., Turek, A.M., Wachs, I.E., Huybrechts, D.R.C. and Jacobs, P.A. (1993) Zeolites, 13, 365.
33 Fernandez, A., Leyrer, J., Gonzalez-Elipe, A.R., Munuera, G. and Knozinger, H. (1988) Journal of Catalysis, 112, 489.

34 Mariscal, R., Palacios, J.M., Galan-Fereres, M. and Fierro, J.L.G. (1994) Applied Catalysis A: General, 116, 205.

35 Hanprasopwattana, A., Rieker, T., Sault, A.G. and Datye, A.K. (1997) Catalysis Letters, 45, 165.

36 Hanprasopwattana, A., Srinivasan, S., Sault, A.G. and Datye, A.K. (1996) Langmuir, 12, 3173.

37 Galan-Fereres, M., Alemany, L.J., Mariscal, R., Banares, M.A., Anderson, J.A. and Fierro, J.L.G. (1995) Chemistry of Materials, 7, 1342.

38 Tian, H., Ross, E.I. and Wachs, I.E. (2006) The Journal of Physical Chemistry. B, 110, 9593.

39 Das, N., Eckert, H., Hu, H., Wachs, I.E., Walzer, J.F. and Feher, F.J. (1993) The Journal of Physical Chemistry, 97, 8240.

40 Gao, X., Bare, S.R., Weckhuysen, B.M. and Wachs, I.E. (1998) The Journal of Physical Chemistry. B, 102, 10842.

41 Oyama, S.T., Went, G.T., Lewis, K.B., Bell, A.T. and Somorjai, G.A. (1989) The Journal of Physical Chemistry, 93, 6786.

42 Resini, C., Montanari, T., Busca, G., Jehng, J.M. and Wachs, I.E. (2005) Catalysis Today, 99, 105.

43 Banares, M.A., Cardoso, J.H., Agullo-Rueda, F., Correa-Bueno, J.M. and Fierro, J.L.G. (2000) Catalysis Letters, 64, 191.

44 Gao, X. and Wachs, I.E. (2002) Topics in Catalysis, 18, 243.

45 Went, G.T., Oyama, S.T. and Bell, A.T. (1990) The Journal of Physical Chemistry, 94, 4240.

46 Burcham, L.J., Datka, J. and Wachs, I.E. (1999) The Journal of Physical Chemistry. B, 103, 6015.

47 Baltes, M., Kytokivi, A., Weckhuysen, B.M., Schoonheydt, R.A., van der Voort, P. and Vansant, E.F. (2001) The Journal of Physical Chemistry. B, 105, 6211. 
48 Kim, D.S. and Wachs, I.E. (1993) Journal of Catalysis, 142, 166.

49 Jehng, J.-M., Tung, W.-C., Huang, C.-H. and Wachs, I.E. (2007) Microporous and Mesoporous Materials, 99, 299.

50 Tanaka, T., Nojima, H., Yamamoto, T., Takenaka, S., Funabiki, T. and Yoshida, S. (1999) Physical Chemistry Chemical Physics, 1, 5235.

51 Weckhuysen, B.M., Wachs, I.E. and Schoonheydt, R.A. (1996) Chemical Reviews, 96, 3327.

52 Doornkamp, C., Clement, M., Gao, X., Deo, G., Wachs, I.E. and Ponec, V. (1999) Journal of Catalysis, 185, 415.

53 Banares, M.A., Hu, H. and Wachs, I.E. (1995) Journal of Catalysis, 155, 249.

54 Jehng, J.M., Hu, H., Gao, X. and Wachs, I.E. (1996) Catalysis Today, 28, 335.

55 Lee, E.L. and Wachs, I.E. (2007) The Journal of Physical Chemistry. C, 111, 14410.

56 Lee, E.L. and Wachs, I.E. (2008) The Journal of Physical Chemistry. C, 112, 6487.

57 Mestl, G. and Srinivasan, T.K.K. (1998) Catalysis Reviews - Science and Engineering, 40, 451.

58 Wachs, I.E. (2005) Catalysis Today, 100, 79.

59 Brown, F.R., Makovsky, L.E. and Rhee, K.H. (1977) Applied Spectroscopy, 31, 563.

60 Brown, F.R., Makovsky, L.E. and Rhee, K.H. (1977) Journal of Catalysis, 50, 162.

61 Brown, F.R., Makovsky, L.E. and Rhee, K.H. (1977) Journal of Catalysis, 50, 385.

62 Thomas, R., Moulijn, J.A. and Kerkhof, F.P.J.M. (1977) Recueil des Travaux Chimiques des Pays-Bas, 96, 134.

63 Roozeboom, F., Mittelmeijer-Hazeleger, M.C., Moulijn, J.A., Medema, J., De Beer, V.H.J. and Gellings, P.J. (1980) The Journal of Physical Chemistry, 84, 2783.

64 Roozeboom, F., Medema, J. and Gellings, P.J. (1978) Zeitschrift fuer Physikalische Chemie, 111, 215.

65 Kerkhof, F.P.J.M., Moulijn, J.A. and Thomas, R. (1979) Journal of Catalysis, 56, 279.
66 Chan, S.S., Wachs, I.E., Murrell, L.L., Wang, L. and Hall, W.K. (1984) The Journal of Physical Chemistry, 88, 5831.

67 Cheng, C.P., Ludowise, J.D. and Schrader, G.L. (1980) Applied Spectroscopy, 34, 146.

68 Wang, L. and Hall, W.K. (1983) Journal of Catalysis, 82, 177.

69 Stencel, J.M., Makovsky, L.E., Sarkus, T.A., De Vries, J., Thomas, R. and Moulijn, J.A. (1984) Journal of Catalysis, 90, 314.

70 Stencel, J.M., Makovsky, L.E., Diehl, J.R. and Sarkus, T.A. (1984) Journal of Raman Spectroscopy, 15, 282.

71 Weckhuysen, B.M., Jehng, J.-M. and Wachs, I.E. (2000) The Journal of Physical Chemistry. B, 104, 7382.

72 Banares, M.A. and Wachs, I.E. (2002) Journal of Raman Spectroscopy, 33, 359.

73 Nakamoto, K. (1986) Infrared and Raman Spectra of Inorganic and Coordination Compounds, 4th edn, John Wiley \& Sons, New York, NY.

74 Banwell, C.N. (1983) Fundamentals of Molecular Spectroscopy, 3rd edn, McGrawHill, London.

75 Busca, G. (2002) Journal of Raman Spectroscopy, 33, 348.

76 Galeener, F.L. and Mikkelsen, J.C. Jr. (1981) Physical Review B: Condensed Matter, 23, 5527.

77 Gao, X. and Wachs, I.E. (2000) Journal of Catalysis, 192, 18.

78 Gao, X. and Wachs, I.E. (1999) Catalysis Today, 15, 233.

79 Gao, X., Bare, S.R., Fierro, J.L.G., Banares, M.A. and Wachs, I.E. (1998) The Journal of Physical Chemistry. B, 102, 5653.

80 Yudaev, I.V., Gan, Z., Paukshtis, E.A., Wachs, I.E. and Lapina, O.B., unpublished.

81 Turek, A.M., Wachs, I.E. and DeCanio, E. (1992) The Journal of Physical Chemistry, 96, 5000 .

82 Sanderson, R.T. (1988) Journal of Chemical Education, 65, 112.

83 Ostromecki, M.M., Burcham, L.J. and Wachs, I.E. (1998) Journal of Molecular Catalysis A: Chemical, 132, 59. 
$22 \mid 1$ Use of Oxide Ligands in Designing Catalytic Active Sites

84 Dobler, J., Pritzsche, M. and Sauer, J. (2005) Journal of the American Chemical Society, 127, 10861.

85 Magg, N., Immaraporn, B., Giorgi, J.B., Schroeder, T., Baumer, M., Dobler, J., Wu, Z., Kondratenko, E., Cherian, M., Baerns, M., Stair, P.C., Sauer, J. and Freund, H.J. 2004 Journal of Catalysis, 226, 88

86 Avdeev, V.I. and Zhidomirov, G.M. (2004) Research on Chemical Intermediates, 30, 41.

87 Lee, E.L. and Wachs, I.E. (2008) Journal of Catalysis, 258, 103.

88 Lee, E.L. and Wachs, I.E. (1991) The Journal of Physical Chemistry, accepted.

89 Gao, X., Fierro, J.L.G. and Wachs, I.E. (1999) Langmuir, 15, 3169.

90 Gao, X., Bare, S.R., Fierro, J.L.G. and Wachs, I.E. (1999) The Journal of Physical Chemistry B, 103, 618.

91 Banares, M.A., Spencer, N.D., Jones, D. and Wachs, I.E. (1994) Journal of Catalysis, 146, 204.

92 Hardcastle, F.D. and Wachs, I.E. (1991) The Journal of Physical Chemistry, 95, 10763.

93 Desikan, A.N., Huang, L. and Oyama, S.T. (1991) The Journal of Physical Chemistry, 95, 10050.

94 Williams, C.C., Ekerdt, J.G., Jehng, J.-M., Hardcastle, F.D., Turek, A.M. and Wachs, I.E. (1991) The Journal of Physical Chemistry, 95, 8781.

$95 \mathrm{Hu}, \mathrm{H} .$, Wachs, I.E. and Bare, S.R. (1995) The Journal of Physical Chemistry, 99, 10897.

96 Banares, M.A., Hu, H. and Wachs, I.E. (1994) Journal of Catalysis, 150, 407.

97 Cornac, M., Janin, A. and Lavalley, J.C. (1986) Polyhedron, 5, 183.

98 Seyedmonir, S.R. and Howe, R.F. (1988) Journal of Catalysis, 110, 216.

99 Ohler, N. and Bell, A.T. (2005) The Journal of Physical Chemistry. B, 109, 23419.

100 Chempath, S., Zhang, Y. and Bell, A.T. (2007) The Journal of Physical Chemistry. C, 111, 1291.

101 Wachs, I.E. (1996) Catalysis Today, 27, 437.
102 Vuurman, M.A. and Wachs, I.E. (1992) The Journal of Physical Chemistry, 96, 5008.

103 Vuurman, M.A., Stufkens, D.J. and Oskam, A. (1992) Journal of Molecular Catalysis, 76, 263.

104 Kim, D.S. and Wachs, I.E. (1993) Journal of Catalysis, 141, 419.

105 Weber, R.S. (1995) Journal of Catalysis, 151, 470.

106 Gao, X. and Wachs, I.E. (2000) The Journal of Physical Chemistry. B, 104, 1261.

107 Ross-Medgaarden, E.I. and Wachs, I.E. (2007) The Journal of Physical Chemistry. C, 111, 15089.

108 Wachs, I.E., Chen, Y., Jehng, J.-M., Briand, L.E. and Tanaka, T. (2003) Catalysis Today, 78, 13.

109 Wright, A.C. (1984) Philosophical Magazine B, 50, L23.

110 Ng, H.N. and Calvo, C. (1972) Canadian Journal of Chemistry, 50, 3619.

111 Busca, G., Ricchiardi, G., Sam, D.S.H. and Volta, J.C. (1994) Journal of the Chemical Society, Faraday Transactions, 90, 1161.

112 Marumo, F., Isobe, M., Iwai, S. and Kondo, Y. (1974) Acta Crystallographica, B30, 1628.

113 Evans, H.T. (1960) Zeitschrift fur Kristallographie, 114, 257.

114 Gopal, R. and Calvo, C. (1974) Acta Crystallographica, B30, 2491.

115 Wachs, I.E. (2005) Molecular structures of surface metal oxide species: nature of catalytic active sites in mixed metal oxides, in Metal Oxides: Chemistry and Applications (eds. J.L.G. Fierro and H. Heinemann), CRC Taylor \& Francis Press.

116 Wells, A. (1984) Structural Inorganic Chemistry, Oxford University, London.

117 Greenwood, N.N. and Earnshaw, A. (1989) Chemistry of the Elements, Pergamon Press, Elmsford, NY.

118 Knopnadel, I., Hartl, H., Hunnius, W.D. and Fuchs, J. (1974) Angewandte Chemie International Edition, 86, 894. 
119 Hove, A.R., Bildsoe, H., Skibsted, J., Brorson, M. and Jakobsen, H.J. (2006) Inorganic Chemistry, 45, 10873.

120 Hardcastle, F.D. and Wachs, I.E. (1990) Journal of Raman Spectroscopy, 21, 683.

121 Spitaler, J., Ambrosch-Draxl, C., Nachbaur, E., Belaj, F., Gomm, H. and Netzer, F. (2003) Physical Review B: Condensed Matter, 67, 115127.

122 Lock, C.J.L. and Turner, G. (1975) Acta Crystallographica, B31, 1764.

123 Pendharkar, A.V. and Mande, C. (1973) Pramana, 1, 104.

124 Swainson, I.P. and Brown, R.J.C. (1997) Acta Crystallographica, B53, 76.

125 Badlani, M. and Wachs, I.E. (2001) Catalysis Letters, 75, 137.

126 Wang, X. and Wachs, I.E. (2004) Catalysis Today, 96, 211.
127 Kim, T., Burrows, A., Kiely, C.J. and Wachs, I.E. (2007) Journal of Catalysis, 246, 370.

128 Wachs, I.E., Jehng, J.-M. and Ueda, W. (2005) The Journal of Physical Chemistry. B, 109, 2275.

129 Burcham, L.J., Briand, L.E. and Wachs, I.E. (2001) Langmuir, 17, 6164.

130 Burcham, L.J., Deo, G., Gao, X. and Wachs, I.E. (2000) Topics in Catalysis, 11/12, 85.

131 Tatibouet, J.M. (1997) Applied Catalysis A: General, 148, 213.

132 Redhead, P.A. (1962) Vacuum, 12, 213.

133 Kim, T. and Wachs, I.E., Ph.D. Thesis.

134 Bronkema, J.L. and Bell, A.T. (2007) The Journal of Physical Chemistry. C, 111, 420.

135 Boudart, M. (1995) Chemical Reviews, 95, 661. 
